

\section{MARSHALL ISLANDS}

GENDER EQUALITY OVERVIEW KEY STATISTICS FOR INFORMED DECISION-MAKING

IN CELEBRATION OF BEIJING+25

DECEMBER 2020 
(C) 2020 Asian Development Bank

6 ADB Avenue, Mandaluyong City, 1550 Metro Manila, Philippines

Tel +632 8632 4444; Fax +63286362444

www.adb.org

Some rights reserved. Published in 2020.

ISBN 978-92-9262-524-5 (print); 978-92-9262-525-2 (electronic); 978-92-9262-526-9 (ebook)

Publication Stock Number: ARM200347-2

https://dx.doi.org/10.22617/ARM200347-2

The views expressed in this publication are those of the authors and do not necessarily reflect the views and policies of the Asian Development Bank (ADB) or its Board of Governors or the governments they represent.

ADB does not guarantee the accuracy of the data included in this publication and accepts no responsibility for any consequence of their use. The mention of specific companies or products of manufacturers does not imply that they are endorsed or recommended by ADB in preference to others of a similar nature that are not mentioned.

By making any designation of or reference to a particular territory or geographic area, or by using the term "country" in this document, $A D B$ does not intend to make any judgments as to the legal or other status of any territory or area.

This work is available under the Creative Commons Attribution 3.0 IGO license (CC BY 3.0 IGO)

https://creativecommons.org/licenses/by/3.o/igo/. By using the content of this publication, you agree to be bound by the terms of this license. For attribution, translations, adaptations, and permissions, please read the provisions and terms of use at https://www.adb.org/terms-use\#openaccess.

This CC license does not apply to non-ADB copyright materials in this publication. If the material is attributed to another source, please contact the copyright owner or publisher of that source for permission to reproduce it. $\mathrm{ADB}$ cannot be held liable for any claims that arise as a result of your use of the material.

Please contact pubsmarketing@adb.org if you have questions or comments with respect to content, or if you wish to obtain copyright permission for your intended use that does not fall within these terms, or for permission to use the ADB logo.

Corrigenda to ADB publications may be found at http://www.adb.org/publications/corrigenda.

Notes:

In this publication, “\$” refers to United States dollars.

All photos by $A D B$.

On the cover: Woman doing handicrafts work in Majuro, Marshall Islands; Kids stroll in the streets of Ebeye; an oceanscape in the Republic of Marshall Islands (photos by ADB; cover design by Edith Creus). 


\section{Contents}

Tables, Figures, and Box

1 Introduction $\quad 1$

2 Data Sources $\quad 4$

Population and Housing Census (2011) 4

Demographic and Health Survey (2007) 4

Family Health and Safety Study (2012) 4

Labour Force Survey (2012)

Household Income and Expenditure Survey (2002) 5

Administrative Data Sources $\quad 5$

$\begin{array}{lll}3 & \text { About the Marshall Islands } & 7\end{array}$

4 Gender Statistics $\quad 11$

$\begin{array}{ll}\text { Economy } & 11\end{array}$

$\begin{array}{ll}\text { Population } & 13\end{array}$

$\begin{array}{ll}\text { Education } & 17\end{array}$

Health and Well-Being $\quad 20$

Work and Employment $\quad 23$

Gender-Based Violence, Public Safety, and Human Rights 26

Political Participation and Decision-Making $\quad 28$

Environment and Climate Change $\quad 30$

Appendix: Sustainable Development Goals-Data Sources and Availability 32 


\section{Tables and Figures}

\section{Tables}

1 Population by Island or Atoll, Marshall Islands, 2011

2 Literacy Rates in the Marshall Islands, $2011 \quad 18$

3 Enrollment in National Training Programs, $2013 \quad 18$

4 Life Expectancy, Fertility and Mortality Rates in the Marshall Islands, 201120

5 Main Causes of Death in the Marshall Islands, 2016

6 Data on Employment- and Unemployment-to-Population Ratio, Marshall Islands, 2011

7 Number of Police Officers, by Sex and Police Force, 2017

8 Ranking of Pacific Island Countries by the Proportion of Land and Marine (Exclusive Economic Zone) 30 Area Under Protection, 2015

9 Major Weather Events, 1979-2019

\section{Figures}

1 Current Availability of Gender-Related Sustainable Development Goal Indicators in the Marshall Islands

2 Real Gross Domestic Product (GDP) Growth (\%), FY2010-FY2018 11

3 Annual Gross Domestic Product, 2010-2018 (current prices) 11

4 Contribution to Gross Domestic Product, by Industry, 2016 (\%, at constant prices) 12

5 Annual Gross Domestic Product Per Capita, 2010-2018 (at constant prices) 12

6 Age-Sex Structure of Total Population, 2011

7 Total Fertility Rate (average number of children per woman), 1964-2011 14

8 Population Size and Growth Rate, 1920-2035 15

9 Gender Parity Index, by Level of Education, 2011

10 Male Education Status, 2011 (age 5-18) 17

11 Female Education Status, 2011 (age 5-18) 17

12 Net Enrollment Ratios, by Level of Education and Sex 18

13 Primary School Completion Rate for Adults (age 25+) 19

14 Secondary School Completion Rate (age 25+) 19

15 Highest Education Attainment Among Age 25+, by Sex, 201120

16 Teenage Mothers as Percentage of All Registered Births, 2008-2016 21

17 Percentage of Households with Access to Decent Water and Sanitation, 200722 
18 Percentage of Children Age 0-5 Who Are Malnourished Based on Assessment of Thinness and Swelling of Feet, 2007

19 Number of Marshall Islands Children Adopted Overseas, by Sex, 2010-2017

20 Prevalence of Disability, by Sex and Number of Disabilities, 2011

21 Economic Activity Status of Population Age 15+, by Sex, 2011

22 Employment-to-Population Ratio in Urban Areas, by Age Group, 2011

23 Employment-to-Population Ratio in Rural Areas, by Age Group, 2011

24 Employment Status of Population Age 15+, by Sex, 2011

25 Average Annual Income Population Age 15+, by Sex and Island/Atoll, 2011 (\$)

26 Share of Women in Paid Employment, Population Age 15+, by Sector and Sex, 2011

27 Number of Persons Arrested, by Sex, 2010-2016

28 Number of Persons in Union/Married, by Age and Sex, 2011

29 Prevalence of Intimate Partner Violence among Ever-Partnered Women, 2012

30 Share of Parliamentary Seats, by Sex, 2020

31 Number of Judges in the Marshall Islands Judiciary, by Sex (2010-2017)

29

32 Proportion of Women in the National Parliament, 2019 


\section{Acknowledgments}

This publication was prepared as part of technical assistance on Promoting Evidence-Based Policy Making for Gender Equity in the Pacific (Phase II) led by Ritu Verma, principal social development specialist and Mairi McRae, social development specialist, Asian Development Bank (ADB). This publication was made possible through the valued inputs of Joyceline Mellan, gender statistics focal point, Economic Policy, Planning and Statistics Office, Government of the Marshall Islands; the staff of the Economic Policy, Planning and Statistics Office; Gillian Biscoe, international consultant; and Jessica Gardner, international gender statistics consultant. They compiled the data and oversaw the process of developing this report. The authors would like to thank Leah Gutierrez, director general, Pacific Department (PARD), ADB; Paul Curry, country team leader for the Marshall Islands; and Ellen Paul, senior country officer, PARD for their support for this publication. Special appreciation goes to Emma Veve, deputy director general, PARD, ADB for her insights and invaluable support. Thank you to Molly Helkena, assistant secretary at the Ministry of Cultural and Internal Affairs, for her support in this work, and to the ministries and agencies in the Marshall Islands that responded promptly and generously to requests for data. The authors are grateful to Emma Jimenez-Nava, associate project analyst for technical assistance support; Leah Castro, senior operations assistant for administrative support; and Cecilia Caparas, associate knowledge management officer, for their support in the publishing process.

\section{Further Information}

The Economic Policy, Planning and Statistics Office of the Marshall Islands has the lead role in the collection and analysis of data, including gender statistics. For further information on Marshall Islands gender and other statistics, please contact the Economic Policy, Planning and Statistics Office at PO Box 7, Majuro, Marshall Islands 96960. Phone +6926253802 or 6253803 . 




\section{Introduction}

This publication presents gender statistics for the Marshall Islands. It also provides a brief overview of the Marshall Islands to give context to the statistics. Gender statistics assist in the monitoring and evaluation of gender equity progress and inform future gender equality policy, plans, and implementation. Gender equality is central to the achievement of sustainable development. That this document coincides with the Beijing $25+$, the twenty-fifth anniversary of the original fourth world conference on women in Beijing, is a significant milestone, and a reminder of the importance of government efforts in advancing progress on gender equality.

The gender statistics were derived from the latest key data collections in the Marshall Islands. These include the 2011 Population and Housing Census, the 2007 Demographic and Health Survey, the 2012 Family Health and Safety Study, the 2012 Labour Force Survey, and data from the education and health sectors.

Gender statistics is an established field of statistics for gender analysis and monitoring that uses sex-disaggregated data from the social, economic, and environment sectors. Gender statistics uses (i) sex-disaggregated data; (ii) data relevant to gender equality (e.g., unpaid household work, gender parity in education and work); (iii) gender-sensitive concepts, definitions, and language; and (iv) data collections that have no gender bias (e.g., through questionnaire design and interviewer training). ${ }^{1}$

There are 80 gender-related indicators across the 17 Sustainable Development Goals (SDGs). ${ }^{2}$ One in ten indicators (11\%) is still being developed globally. For the remainder, the Marshall Islands can produce $54 \%$ of the indicators from existing sources (Figure 1). The Marshall Islands is preparing for its next national population and housing census in 2021, which will provide new sex-disaggregated data, and have a stronger gender focus than in the 2011 census. This will assist progress in comprehensive gender data collection, enabling good monitoring of progress toward the SDGs and gender equity. A detailed analysis of SDG gender-related data sources and gaps in the Marshall Islands is presented in the Appendix to this overview document. 
Figure 1: Current Availability of Gender-Related Sustainable Development Goal Indicators in the Marshall Islands

\section{0 gender-specific or gender-related Sustainable Development Goal Indicators in the global framework}

$$
\text { Number of gender }
$$
indicators

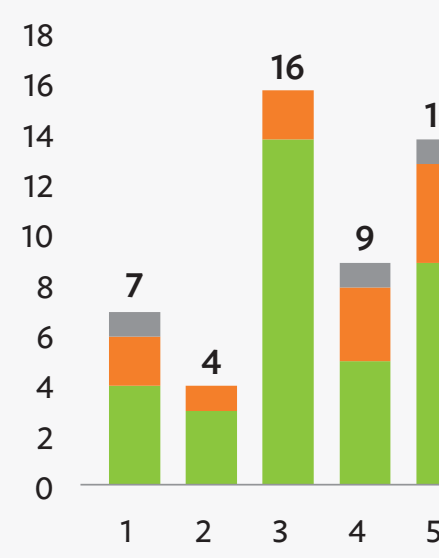

More than half of the global gender indicators can be produced for the Marshall Islands from existing sources.

International methods still under development/not relevant

Not able to produce from existing sources

Able to produce

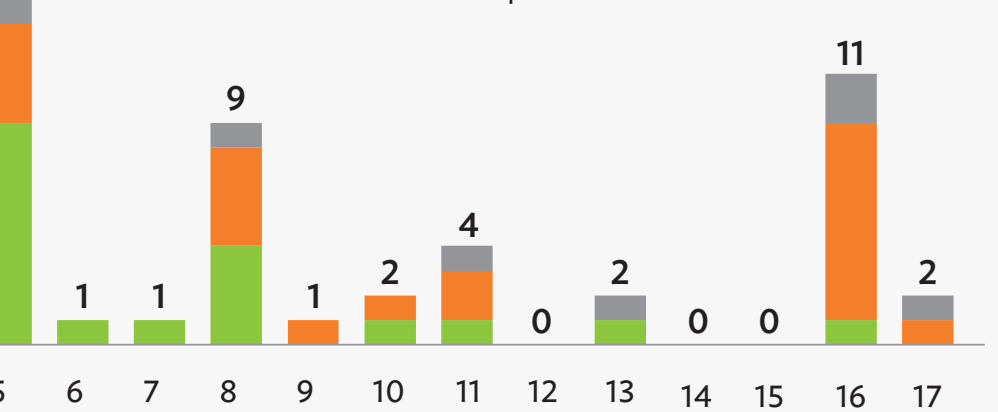

Global Sustainable Development Goals

Sources: Based on the authors' assessment of the latest reports of the Government of the Marshall Islands: The 2011 Population and Housing Census, the 2007 Demographic and Health Survey, the 2012 Family Health and Safety Study, the 2012 Labour Force Survey, the 2002 Household Income and Expenditure Survey, and administrative data. 


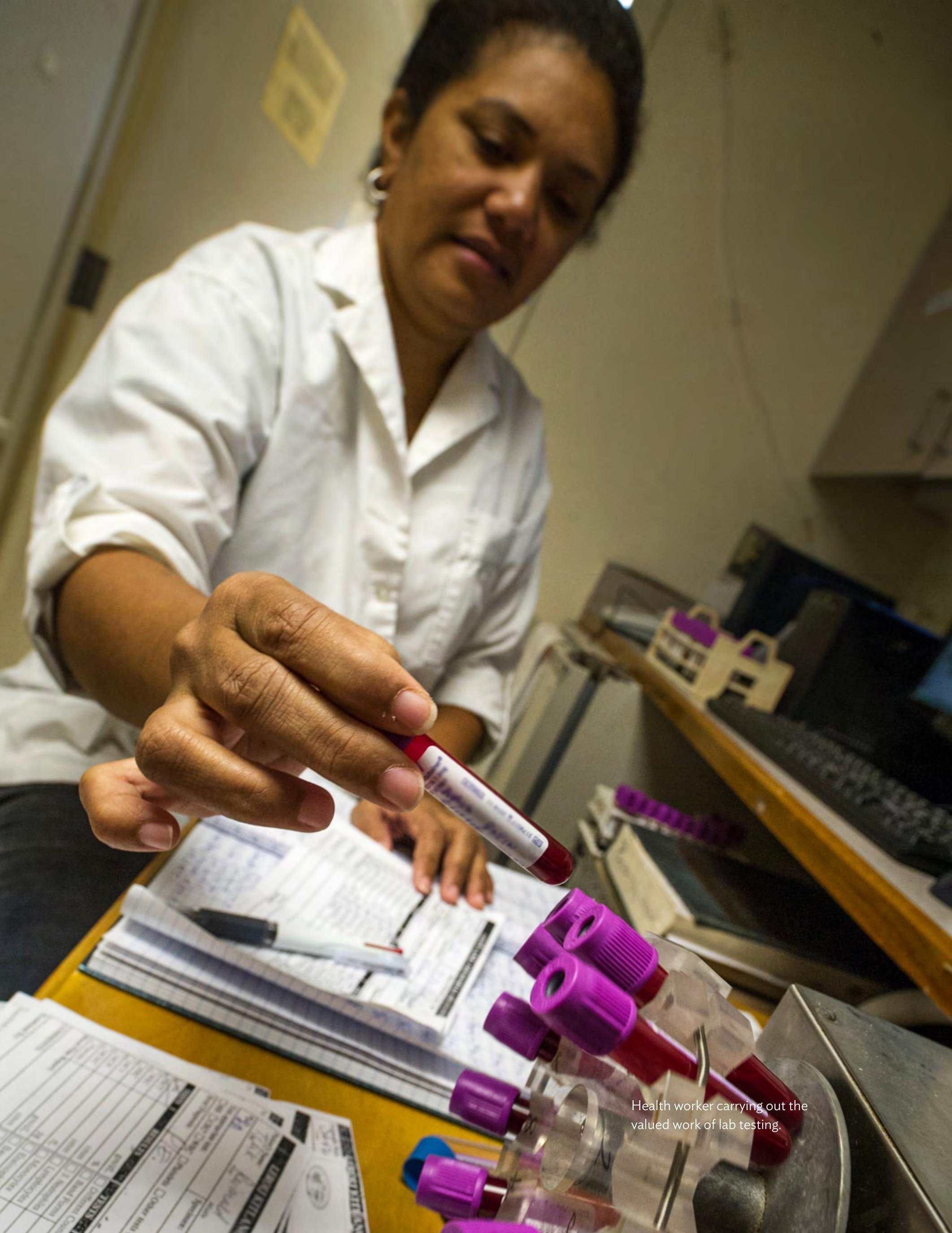




\section{Data Sources}

\section{Population and Housing Census (2011)}

The national population and housing census is conducted every 10 years and is a key data collection for official Marshall Islands statistics, including gender statistics. Census data is disaggregated by sex and other characteristics. The census gathers information on every person and their housing conditions in the Marshall Islands. The results, which are nationally representative, are used to design the sample for subsequent household surveys.

Civil registration data is incomplete in the Marshall Islands (e.g., births, deaths), and the census is one of the main sources for estimating fertility (number of children born) and mortality rates (number of deaths). The census also identifies persons with disabilities, and enables comparison of their situations with the rest of the population. The next population and housing census is planned for 2020.

\section{Demographic and Health Survey (2007)}

The demographic and health survey (DHS) is a major source of gender statistics in the Marshall Islands. The DHS is based on an international standard that (i) assures accurate, reliable, and comparable results on difficultto-measure issues; and (ii) has been used in almost 100 countries globally. The DHS provides information on fertility, family planning, maternal health, infant and child mortality, nutrition, and other characteristics. The DHS includes a section on women's empowerment by using measures relating to economic empowerment, attitudes, and women's involvement in household decision-making. The next DHS, using a methodology combined with a Multiple Indicator Cluster Survey (MICS), is planned for 2021.

\section{Family Health and Safety Study (2012)}

The family health and safety study (FHSS) is a household survey based on well-tested international standards. The FHSS gathers data on women's experiences of violence, an important gender equality concern. The data collected includes the prevalence of intimate partner violence, women's experiences of non-partner violence since age 15, and women's experiences of sexual abuse as a child. The FHSS also gathers qualitative information on the causes and consequences of violence to inform policy and decision makers on this sensitive and often largely hidden problem. 


\section{Labour Force Survey (2012)}

In 2012, a Labour Force Survey (LFS) was conducted in Majuro and Ebeye, the two most populous atolls. The LFS is a household survey that measures employment, unemployment, and the characteristics of people within and outside the labor force based on the latest international standards. An LFS is one way to produce key data such as unemployment and paid work. Through carefully designed questions, the LFS classifies every person of working age (age 15 and above) as employed or self-employed (doing any work for pay or for profit), unemployed (seeking paid work), or outside the labor force.

\section{Household Income and Expenditure Survey (2002)}

In 2002, a Household Income and Expenditure Survey gathered information on income, assets, consumption, and expenses from a nationally representative sample of households. The resulting data provides a basis for producing a range of statistics, including on poverty, expenditure on health and education, and individual income and sociodemographic characteristics. The next Household Income and Expenditure Survey was conducted in 2019.

\section{Administrative Data Sources}

Gender statistics are also produced from administrative data sources, as a byproduct of records kept by government ministries and agencies in the course of their work. This overview includes statistics produced by the Ministry of Education, the Ministry of Health, the Ministry of Internal Affairs, the Marshall Islands Police Department, Majuro Police and Ebeye Police, the Marshall Islands Parliament, Marshall Islands courts, and the Marshall Islands National Disaster Management Office. 


\section{About the Marshall Islands}

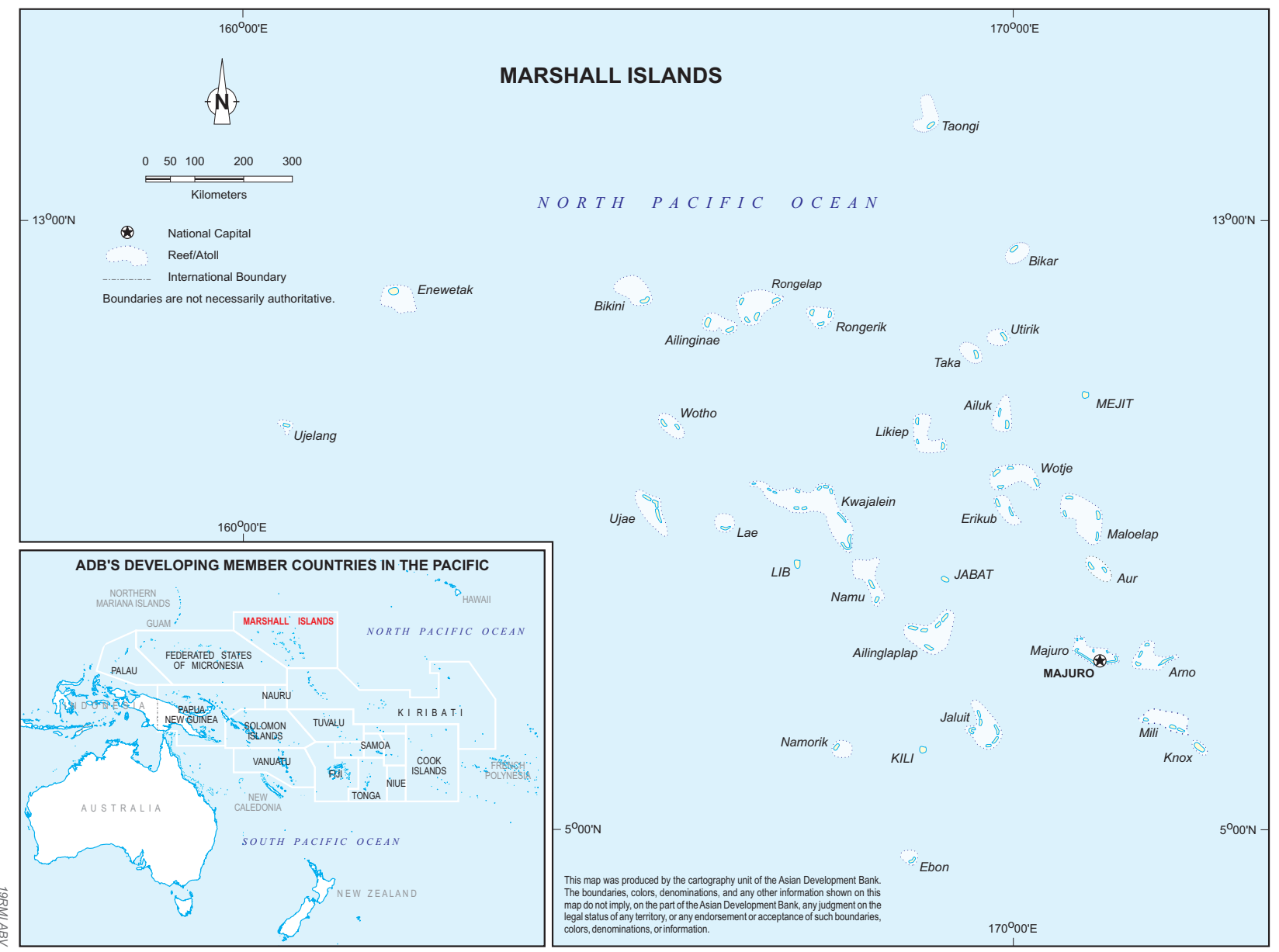

$\begin{array}{ll}\text { Year of independence } & 1979 \\ \text { Land area } & 181 \mathrm{~km}^{2} \\ \text { Exclusive economic zone area } & 2,131,000 \mathrm{~km}^{2} \\ \text { Currency } & \text { United States dollar } \\ \text { Official language } & \text { Marshallese and English } \\ \text { CEDAW ratification } & 2 \text { March 2006 }\end{array}$

$\mathrm{km}^{2}$ = square kilometer, CEDAW = Human Rights Convention for the Elimination of Discrimination against Women.

Source: ADB 
The Marshall Islands is one of the smallest countries in the world with 181 square kilometers of land mass across 29 atolls and islands. It has a population of around 54,000 people (as at the last population census in 2011). Most live in urban settings either in the capital of Majuro (52\% of the population lives there) or the island of Ebeye of the Kwajalein Atoll (22\%).

The Marshall Islands is a self-governing republic in a Compact of Free Association, as amended, with the United States. The Compact, which will end in 2023, provides monetary and other support, including granting Marshall Islands citizens access to live and work in the United States.

The Marshall Islands legislature is bicameral. The 12-member appointed Council of Iroij, made up of traditional leaders, requests the 33-member elected Nitijela to consider bills affecting customary law, land tenure, or any traditional practice. Women can be traditional leaders. The Cabinet is the executive branch of the government, directs the actions of the public service, and is answerable to the Nitijela for its actions. The judiciary consists of a supreme court, a high court, a traditional rights court, and community courts.

The key gender equality legislative efforts are the following:

- Domestic Violence Prevention and Protection Act of 2011

- Child Rights Protection Act of 2015

- Human Rights Committee Act of 2015

- Rights of Persons with Disability Act of 2015

- Birth, Death and Marriage Registration Act of 2016

- Prohibition of Trafficking in Persons Act of 2017

The Marshall Islands has a narrow economic base, limited long-term economic growth and fiscal sustainability, and vulnerability to severe weather and climate change. Economic growth in the last two financial years (2017 and 2018) has been driven by the fishing, construction and transport sectors. There has been a huge increase in donor support with approximately US $\$ 250$ million worth of planned projects funded by the ADB and a number of other multilateral and bilateral development partners. The Graduate School USA highlights that limited local capacity is likely to make implementation a major challenge. The Gross National Income (GNI) per capita was US $\$ 5,175$ in 2018, below the average of $\$ 7,325$ for Pacific island small states published by the World Bank. The social security system is currently unsustainable, with significant mismatch between contributions and benefits despite some recent reforms. Grants have comprised $45 \%-55 \%$ of government revenues in the last 5 financial years (2014-2018). ${ }^{3}$

The Marshall Islands is matrilineal and, culturally, women have high status, although there are high reported rates of intimate partner violence (51\%) and physical violence on children (61\% for girls and $62 \%$ for boys). ${ }^{4}$ The government ratified the Convention on the Elimination of Discrimination against Women (CEDAW) in 2006, and endorsed a national gender policy in 2015. The Marshall Islands had the first woman president in the Pacific countries but in 2011 had only 28\% economic participation of women, and in 2018, 9\% political participation of women (footnote 4). The United Nations Development Programme (UNDP) does not calculate the gender equality index for the Marshall Islands. ${ }^{5}$

3 Graduate School USA. 2019. Economic Brief: RMI FY 2018; and World Bank Data: GNI per capita, PPP (current international \$). Accessed 17 July 2020.

4 Government of the Marshall Islands and Secretariat of the Pacific Community. 2018. Gender Equality. Where Do We Stand? Majuro.

$5 \quad$ United Nations Development Programme (UNDP). 2019. Human Development Report 2019. New York. 
Girls are outperforming boys in all school subjects, except maths and sciences. Proficiency in reading English is low for all (footnote 4). A higher proportion of girls than boys complete year 8 (95\% to 87\%), although fewer girls complete education beyond year 8 (footnote 4). In 2013, however, there was near gender parity in the 979 students enrolled at the post-secondary College of the Marshall Islands. ${ }^{6}$

Health priorities include prevention and treatment of noncommunicable diseases, which are increasing and linked to obesity, are reemerging through urban overcrowding. The nuclear testing conducted in parts of the country in 1954 has resulted in excessive cases of cancer, 530 more than would have been expected in the absence of testing (footnote 4). Of the households, $100 \%$ used improved water for drinking in 2011. ${ }^{7}$ Forty percent of boys and $30 \%$ of girls are stunted, impacting their development throughout life. ${ }^{8}$ Teenage pregnancy rates, while still high, have decreased by $34 \%$ since 2014 from 73 to 48 births per 1,000 women age 15-19 (footnote 4). In 2018, the Pacific average for teenage pregnancy was 51 births per 1,000 women aged 15-19. ${ }^{9}$

National gender-related priorities include eliminating high levels of domestic violence, providing adequate maternal and child health care services to rural and fast-growing urban areas, reducing teenage pregnancy, retaining young men in education, and promoting equal access to economic opportunities.

\section{Impacts of COVID-19 on the Marshall Islands}

As at 19 August 2020, the Marshall Islands has no recorded cases of the coronavirus disease (COVID-19). ${ }^{a}$ The government issued the first COVID-19 related health travel advisories and restrictions on 24 January 2020 requiring all incoming passengers to undergo health checks and get special clearance on arrival. By end of January, all arrivals from the People's Republic of China; Hong Kong, China; and Macau, China were banned as was official government travel to those locations. A state of emergency was declared on 7 February and the National Disaster Committee was required to lead a multi-stakeholder process to plan and coordinate a national preparedness response.

The health system has been preparing by building a COVID-19 isolation ward, training medical staff and raising community awareness. Breaks in school terms have been used to thoroughly clean and sanitize school buildings and extra handwashing facilities have been installed. Most education institutions have continued classes as normal. Some foreign nationals were evacuated through chartered flights to collect Mormon missionaries and Australian citizens. ${ }^{b}$

Expert analysts predict that the major industries in the Marshall Islands-fishing, construction, and transport-will all experience decline. Although only 2.3\% of GDP, the tourism sector will clearly be impacted with the two main hotels virtually empty and no demand on the restaurant sector, which relies on approximately half of its income from visitors. It is anticipated that the economy will shrink in the 2020 financial year (ends 30 September 2020) with a 5.5\% drop in GDP and another $1.4 \%$ in 2021.

continued on next page

Government of the Marshall Islands. 2015. Education for All 2015 National Review Report: Marshall Islands. Majuro.

Government of the Marshall Islands. 2011. Republic of the Marshall Islands 2011 Census Report. Majuro.

Government of the Marshall Islands and United Nations Children's Fund. 2017. Integrated Child Health and Nutrition Survey. Majuro.

World Bank Data: Adolescent fertility rate (births per 1,000 women ages 15-19) - Pacific island small states. Accessed 7 December 2020. 
Box continued

Public sector jobs are unlikely to be impacted but the private sector is expected to be severely impacted with the loss of more than 700 full-time equivalent jobs across sectors. These are expected to hit the loining plant (175 jobs), hotel and restaurant sector (258 jobs) and transport sector (202 jobs). Mitigation is recommended to focus first on ensuring the health sector can respond to COVID-19, with an unemployment and business relief program also recommended.

The gendered impacts of COVID-19 could be significant, especially if the pandemic reaches the Marshall Islands and restrictions on movement are needed to control it. There is increased recognition that social isolation impacts mental health as well as family relationships including increasing gender-based violence. Other gendered impacts will be in the increased care work for children and older persons, which tends to be done more by women than men, and which will grow if schools need to be closed. Women and men will have different roles in managing the food insecurity that is likely to result from declining and delayed imports. The slowing economy could be felt harder by women, who hold less stable employment than men or earn no income of their own.

a World Health Organization. 2020. COVID-19 Pacific Islands Situation Report. WHO.

b DevpolicyBlog. 16 April 2020. Keeping COVID-19 at bay in the Marshall Islands. 


\section{Gender Statistics}

\section{Economy}

The country recorded an improved GDP performance in financial year (FY) 2018 (ended 30 September 2018) with a 3.6\% growth in GDP after 4.1\% in 2017. The main contributor to growth in FY2018 was the manufacturing sector with increases in copra processing value and the Pan Pacific loining plant.

Figure 2: Real Gross Domestic Product Growth, Fiscal Years 2010-2018

(\%)

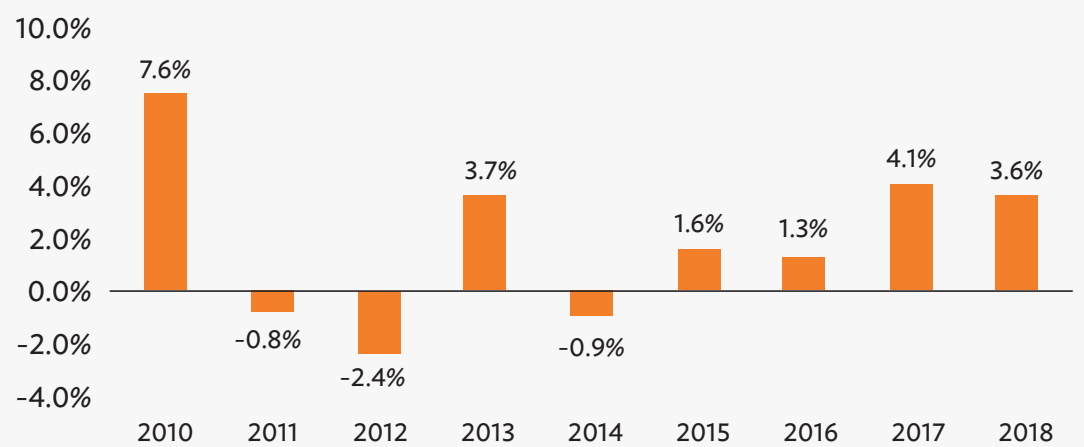

Source: Graduate School USA. 2019. Republic of Marshall Islands Economic Brief: RMI FY 2018.

Figure 3: Annual Gross Domestic Product, 2010-2018

(current prices)

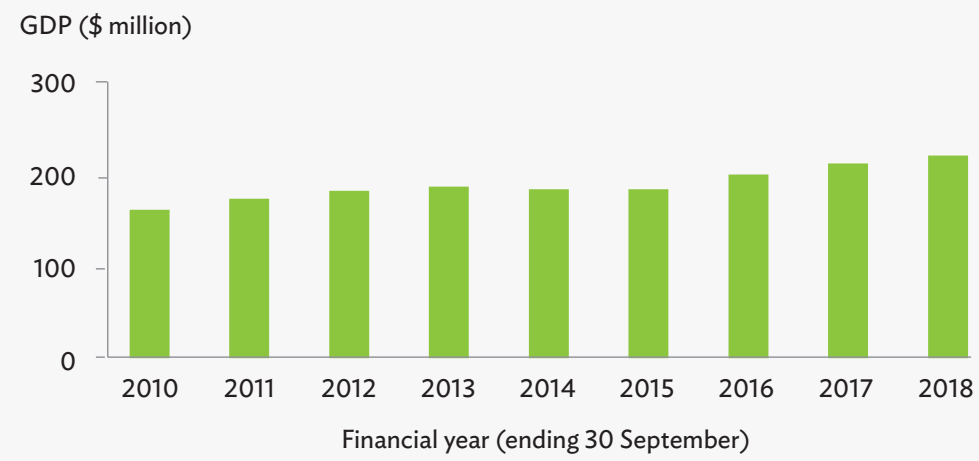

GDP = gross domestic product.

Source: Graduate School of USA. 2016. Republic of the Marshall Islands. Economic Review 2016. Honolulu. 
Figure 4: Contribution to Gross Domestic Product, by Industry, 2016

(\%, at constant prices)

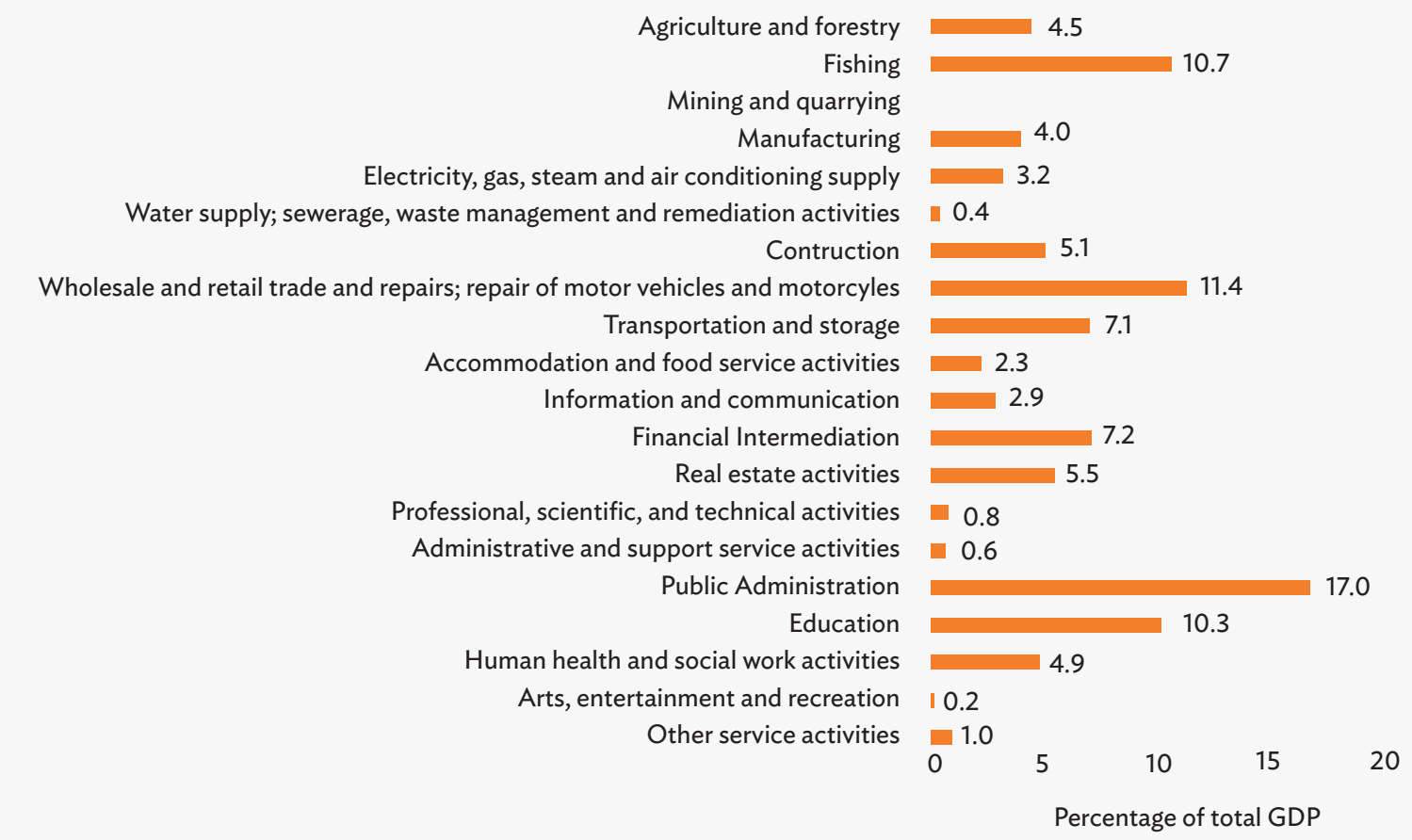

GDP = gross domestic product.

Notes: "Fisheries" includes fish processing and other vessel support services.

Source: Graduate School USA. 2019. Republic of Marshall Islands Economic Brief: RMI FY 2018.

Figure 5: Annual Gross Domestic Product Per Capita, 2010-2018

(at constant prices)

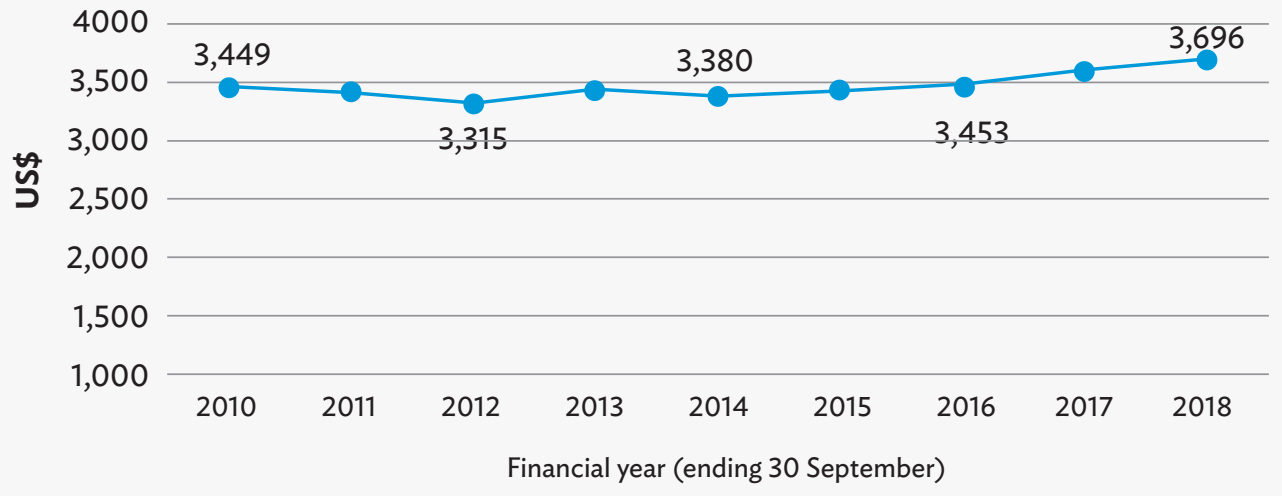

Source: Graduate School USA. 2019. Republic of Marshall Islands Economic Brief: RMI FY 2018. 


\section{Population}

In the 2011 census, 74\% of its approximately 53,000 population lived in the capital, Majuro, and on the island of Ebeye. The average age was 19 and 40\% of the population is less than 15 years old. In 2011, Ebeye had the highest population density in the Marshall Islands at 9,614 people per square mile (2.5 square kilometers).

Population growth had largely halted in 2011 (0.04\% since the previous census in 1999), contributed to by (i) the fertility rate decreasing from 5.7 in 1999 to 4.1 in 2011, (ii) a high death rate, and (iii) high migration. The average household size is 6.8 people nationally, but much higher on the densely populated Ebeye Island (Kwajalein) at 8.3 people per household. The next census is being planned for 2021.

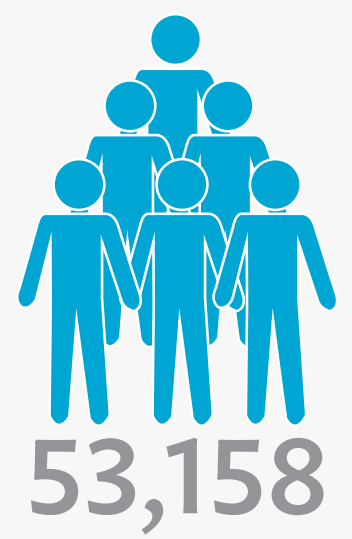

TOTAL POPULATION (2011)

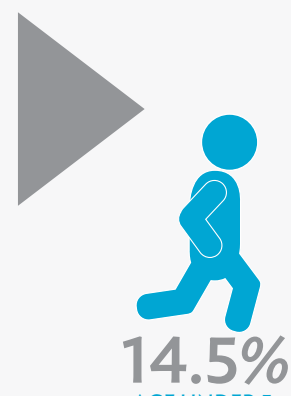

AGE UNDER 5

YEARS
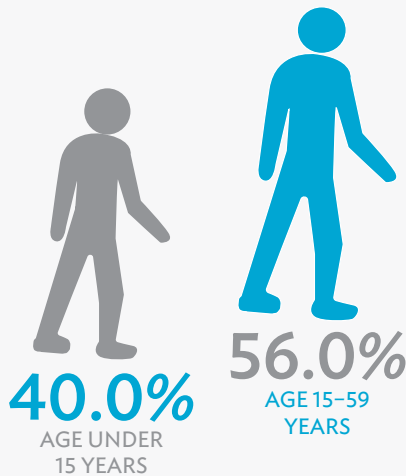

AGE 15-59

YEARS

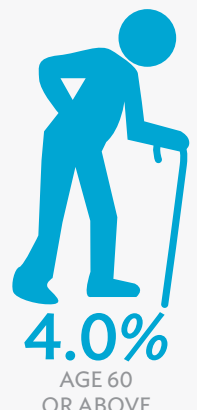

OR ABOVE
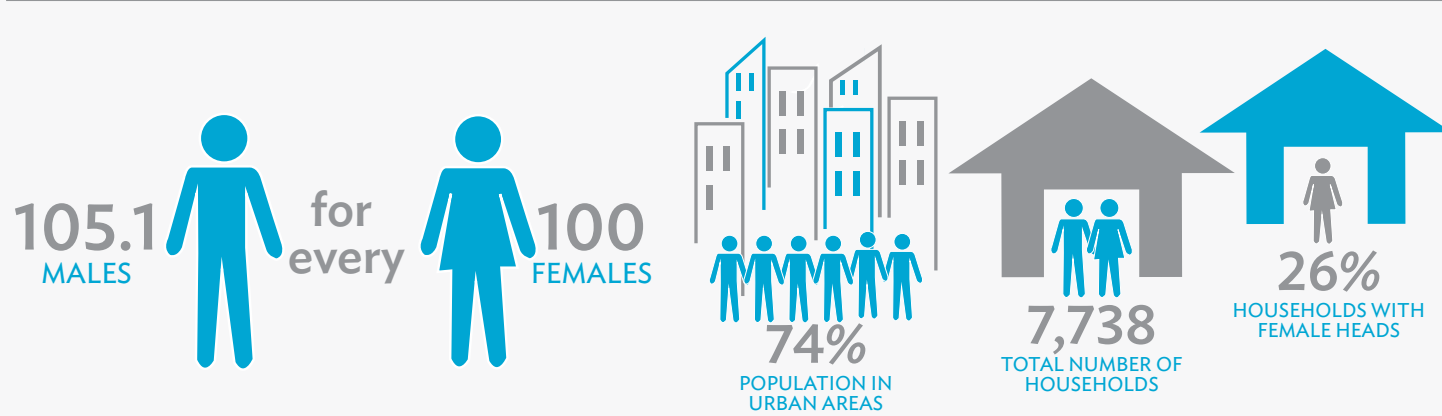

URBAN AREAS

Source: Government of the Marshall Islands. 2011. Republic of the Marshall Islands 2011 Census Report. Majuro. 
Figure 6: Age-Sex Structure of Total Population, 2011

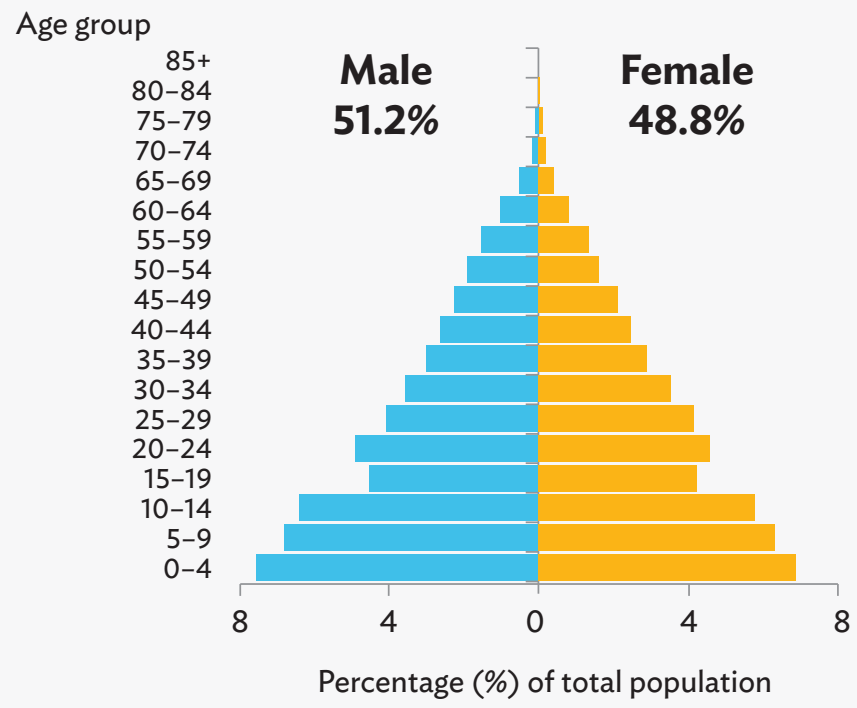

Source: Government of the Marshall Islands. 2011. Republic of the Marshall Islands 2011 Census Report. Majuro.

Fertility rates have declined significantly in recent decades

Figure 7: Total Fertility Rate, 1964-2011

(average number of children per woman)

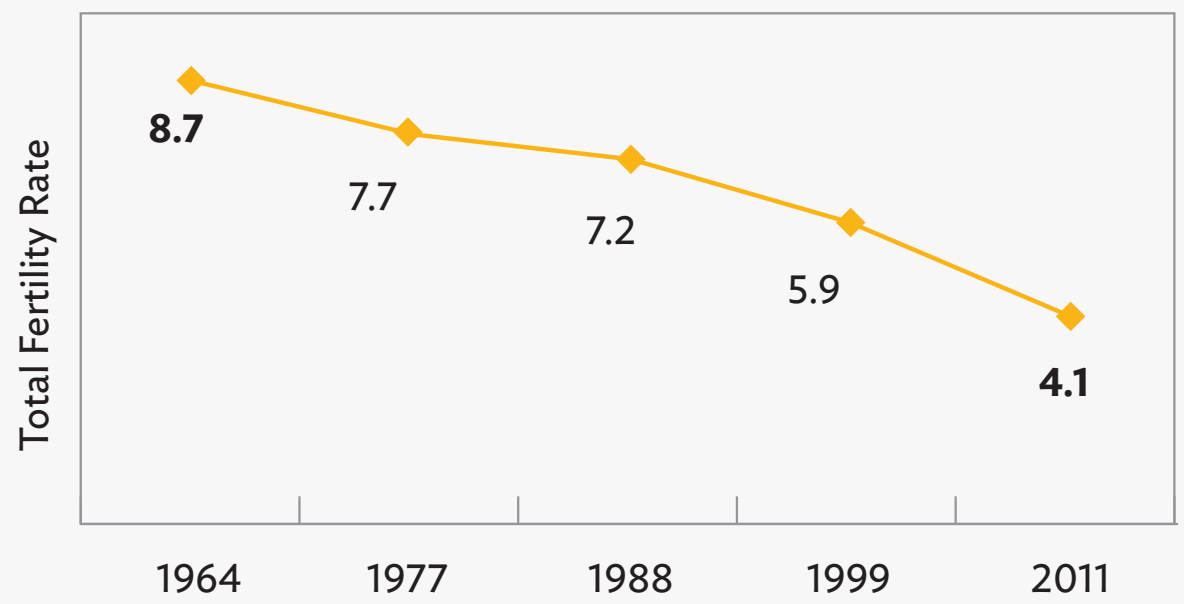

Source: Government of the Marshall Islands. 2011. Republic of the Marshall Islands 2011 Census Report. Majuro. 


\section{Out-migration and lower fertility rates are halting population growth}

Figure 8: Population Size and Growth Rate, 1920-2035

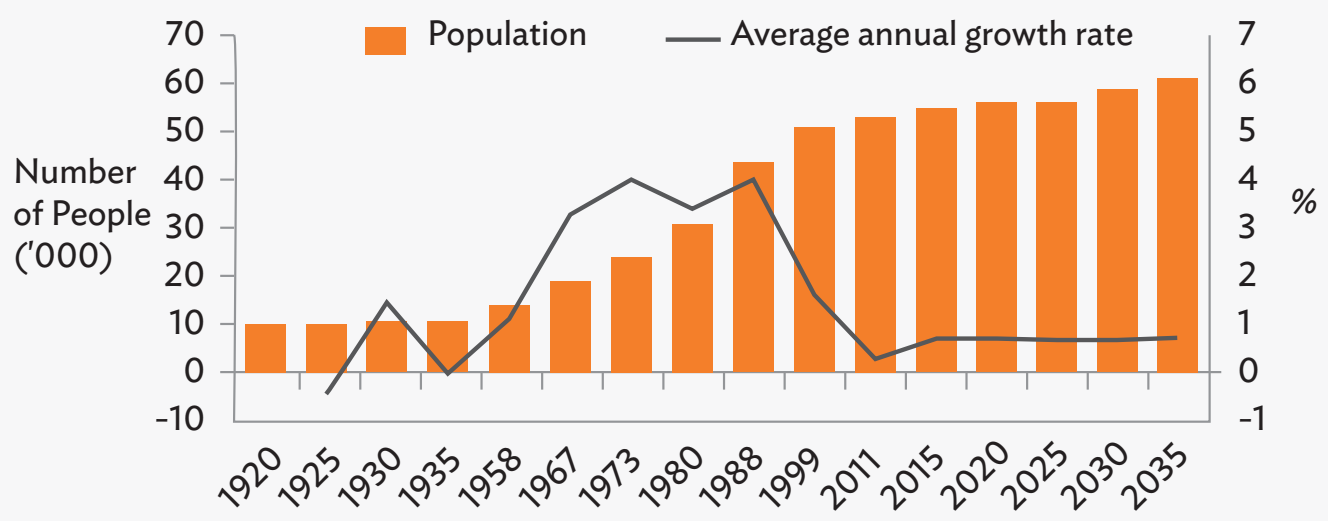

Note: An average annual growth rate of $0.8 \%$ is used for the Secretariat of the Pacific Community population and demographic indicators.

Sources: Government of the Marshall Islands. 2011. Republic of the Marshall Islands 2011 Census Report. Majuro; and Pacific Community (SPC). Population and Demographic Indicators. Noumea (undated). 
Most people live in urban centers of Majuro (52\%) or Kwajalein (22\%)

Table 1: Population by Island or Atoll, Marshall Islands, 2011

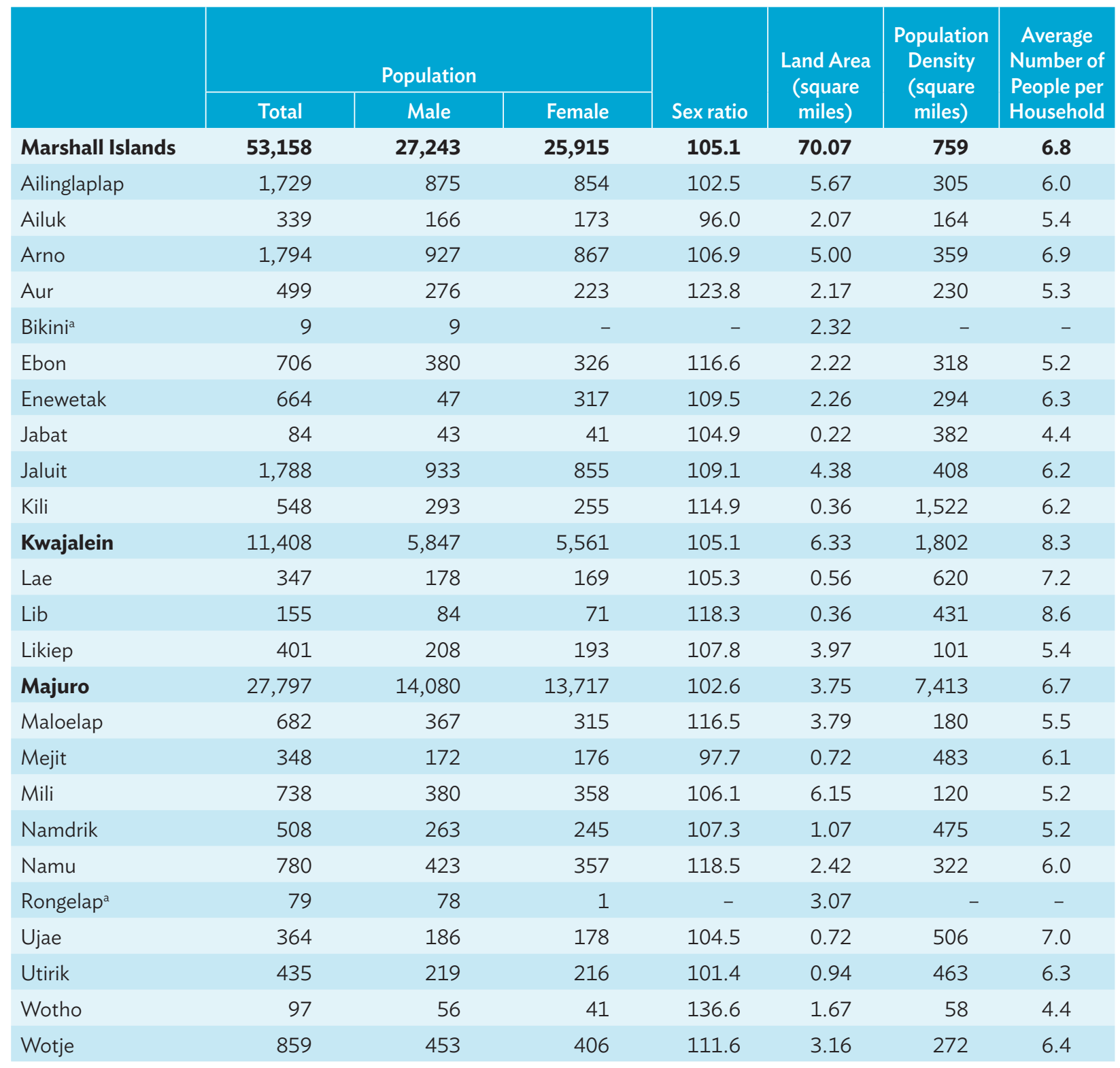

- = data not available.

a Bikini and Rongelap are inhabited by construction workers involved in rehabilitation projects.

Source: Government of the Marshall Islands. 2011. Republic of the Marshall Islands 2011 Census Report. Majuro. 


\section{Education}

The Marshall Islands Public School System Act 2013 makes schooling compulsory between age 5 and age 18 . Education is provided free of charge through public kindergarten (age 5), primary (elementary, age 6-13), and secondary schools (age 14-18).

Private schools make up $14 \%$ of the 93 elementary schools and $65 \%$ of the 17 secondary schools.

\section{More girls than boys attend higher levels of education}

Figure 9: Gender Parity Index, by Level of Education, 2011

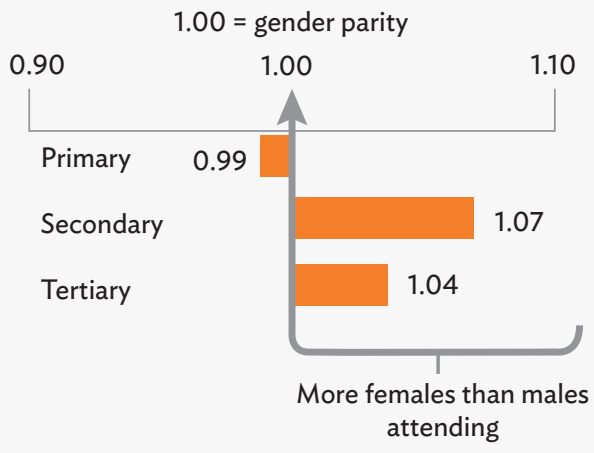

Note: Gender parity index is based on gross attendance ratios; age range used for tertiary education is 19-21 years.

Source: Government of the Marshall Islands. 2011. Republic of the Marshall Islands 2011 Census Report. Majuro.

\section{Universal primary education is still to be achieved. About $80 \%$ of children are attending schools, with little gender gap overall}

Figure 10: Male Education Status, 2011

(age 5-18)

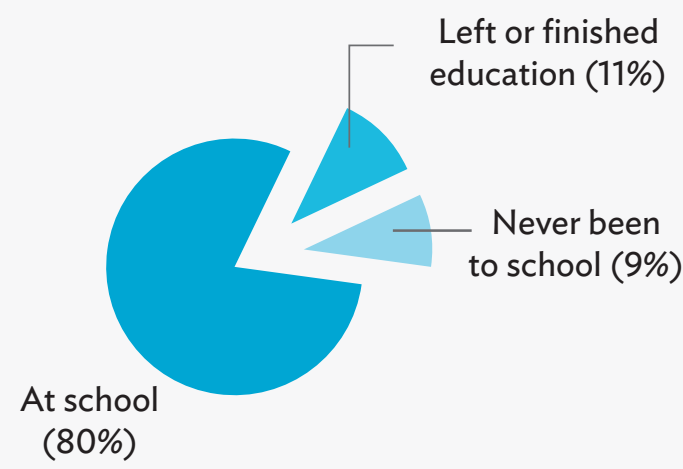

Figure 11: Female Education Status, 2011

(age 5-18)

Left or finished

education (9\%)

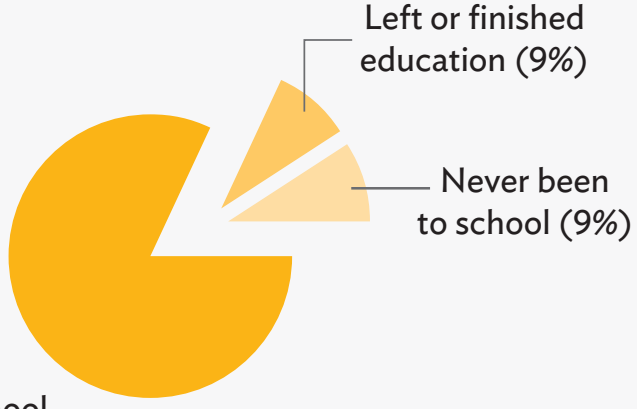

At school

(82\%)

Source: Government of the Marshall Islands. 2011. Republic of the Marshall Islands 2011 Census Report. Majuro. 


\section{Yet, girls are more likely to attend secondary school than boys}

Figure 12: Net Enrollment Ratios, by Level of Education and Sex

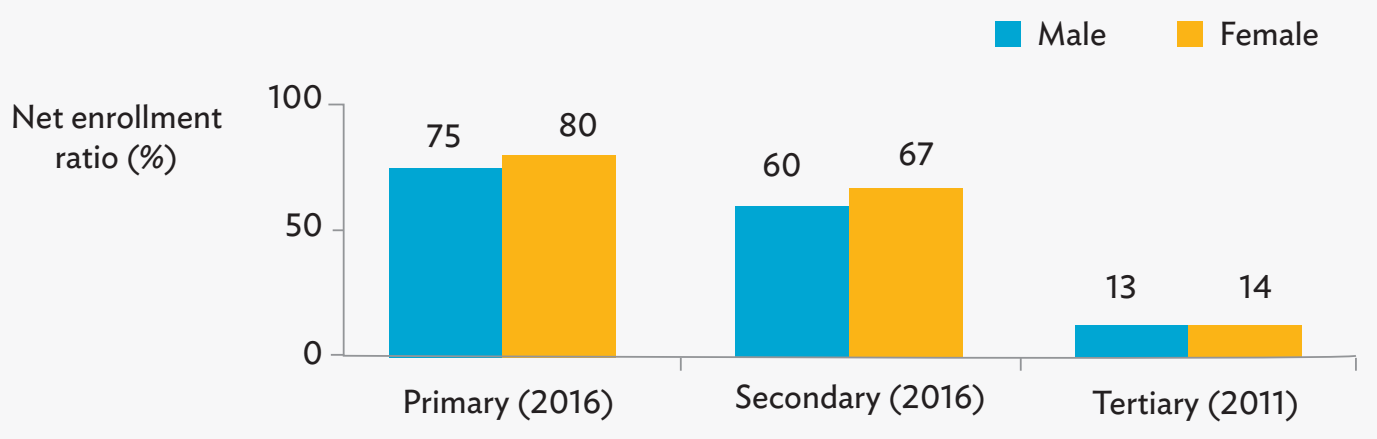

Note: In 2013, compulsory school age changed from 6-14 years to 5-18 years. Age range used for tertiary education is 19-21 years. In the absence of recent sex-disaggregated data on enrollment, attendance data from the 2011 population census have been used.

Sources: Primary and secondary attendance ratios from the United Nations Educational, Scientific, and Cultural Organization (UNESCO) database; tertiary ratio was based on 2011 Population and Housing Census.

Table 2: Literacy Rates in the Marshall Islands, 2011

\begin{tabular}{|c|c|c|}
\hline \multicolumn{3}{|c|}{ Literacy Rates (\%) } \\
\hline & Male & Female \\
\hline Adult (15+) & 95.0 & 95.9 \\
\hline Youth (15-24) & 94.2 & 96.1 \\
\hline
\end{tabular}

Source: Government of the Marshall Islands. 2011. Republic of the Marshall Islands 2011 Census Report. Majuro.

Table 3: Enrollment in National Training Programs, 2013

\begin{tabular}{|lrrr} 
& \multicolumn{2}{c}{ Students Enrolled } & \\
\cline { 2 - 3 } & Male & Female & \% Female \\
Basic education & 25 & 0 & 0 \\
Entrepreneurship & 22 & 83 & 79 \\
Technical-vocational & 205 & 121 & 37
\end{tabular}

Source: Government of the Marshall Islands. 2015. Education for All 2015 National Review Report: Marshall Islands. Majuro. 
For the adult population age 25 and older, the gender gap in highest level of education reached has been narrowing over time. Yet, it remains that, overall, higher percentages of adult men than adult women have completed secondary or tertiary education.

Figure 13: Primary School Completion Rate for Adults (age 25+)

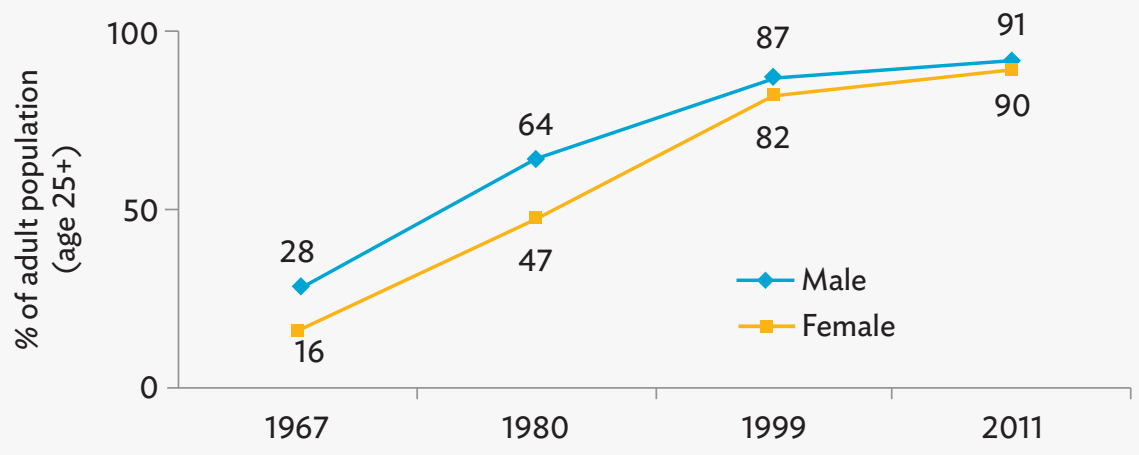

Note: Period of time varies between years shown.

Sources: Government of the Marshall Islands. 2009. Marshall Islands Millennium Development Goal Report (for 1967, 1980, and 1999 data). Majuro; and Government of the Marshall Islands. 2011. Republic of the Marshall Islands 2011 Census Report. Majuro.

Figure 14: Secondary School Completion Rate (age 25+)

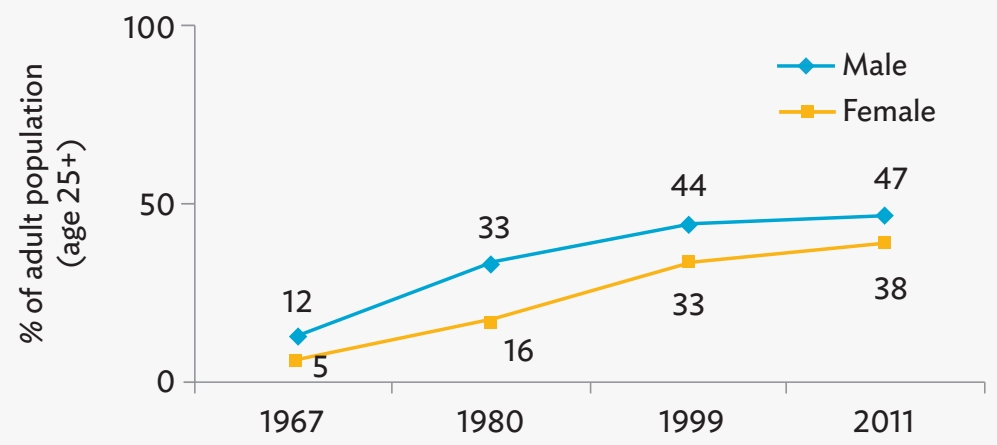

Note: Period of time varies between years shown.

Sources: Government of the Marshall Islands. 2009. Marshall Islands Millennium Development Goal Report (for 1967, 1980, and 1999 data). Majuro; and Government of the Marshall Islands. 2011. Republic of the Marshall Islands 2011 Census Report. Majuro. 
Figure 15: Highest Education Attainment Among Age 25+, by Sex, 2011

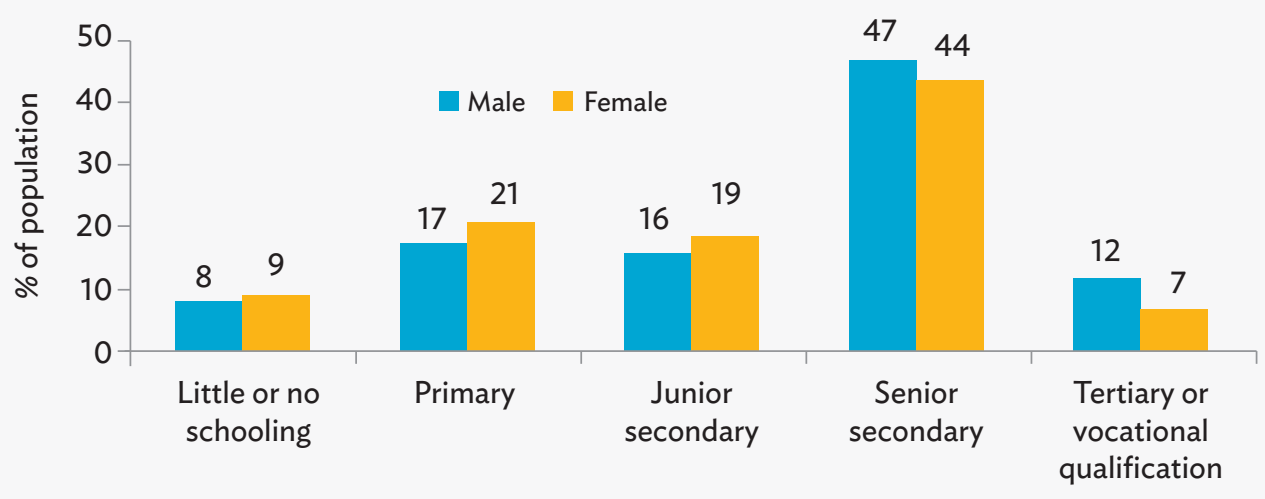

Source: Government of the Marshall Islands. 2011. Republic of the Marshall Islands 2011 Census Report. Majuro.

\section{Health and Well-Being}

Health is a key gender issue with men and women experiencing different health needs and concerns. Maternal and child health are top priorities in the Marshall Islands. ${ }^{10}$ Family planning services and adequate antenatal and postnatal care are essential for these health concerns.

Other health issues for the Marshall Islands include providing support to people impacted by nuclear testing; addressing high rates of teenage pregnancy; supporting people with disabilities, including those with mental health problems; and the prevention and treatment of diabetes and tuberculosis.

Table 4: Life Expectancy, Fertility and Mortality Rates in the Marshall Islands, 2011

\begin{tabular}{|c|c|}
\hline \multicolumn{2}{|c|}{ Life expectancy at birth (years) } \\
\hline Male & 71.3 \\
\hline Female & 72.5 \\
\hline \multicolumn{2}{|c|}{ Fertility rate (average children per woman) } \\
\hline Total & 4.1 \\
\hline Urban & 3.9 \\
\hline Rural & 4.5 \\
\hline \multicolumn{2}{|c|}{ Neonatal mortality rate (per 1,000 live births) ${ }^{a}$} \\
\hline 2010 & 16 \\
\hline 2011 & 17 \\
\hline 2012 & 10 \\
\hline \multicolumn{2}{|c|}{ Infant mortality rate (per 1,000 live births) ${ }^{b}$} \\
\hline Total & 22.0 \\
\hline Male & 24.0 \\
\hline Female & 20.0 \\
\hline \multicolumn{2}{|c|}{$\begin{array}{l}\text { a Neonatal mortality rate refers to deaths occurring before the baby reaches } 28 \text { days. } \\
\text { b Infant mortality refers to deaths before reaching } 12 \text { months (includes neonatal deaths). }\end{array}$} \\
\hline \multicolumn{2}{|c|}{$\begin{array}{l}\text { Sources: Number of maternal deaths from the Ministry of Health Annual Report 2012; all other data are from the } 2011 \text { Population and } \\
\text { Housing Census (Government of the Marshall Islands. 2012. Ministry of Health Annual Report 2012. Majuro; and Government of the } \\
\text { Marshall Islands. 2011. Republic of the Marshall Islands } 2011 \text { Census Report. Majuro.) }\end{array}$} \\
\hline
\end{tabular}

10 Government of the Republic of the Marshall Islands. Ministry of Health Three-Year Rolling Strategic Plan (October 2017-September 2019). Majuro. 


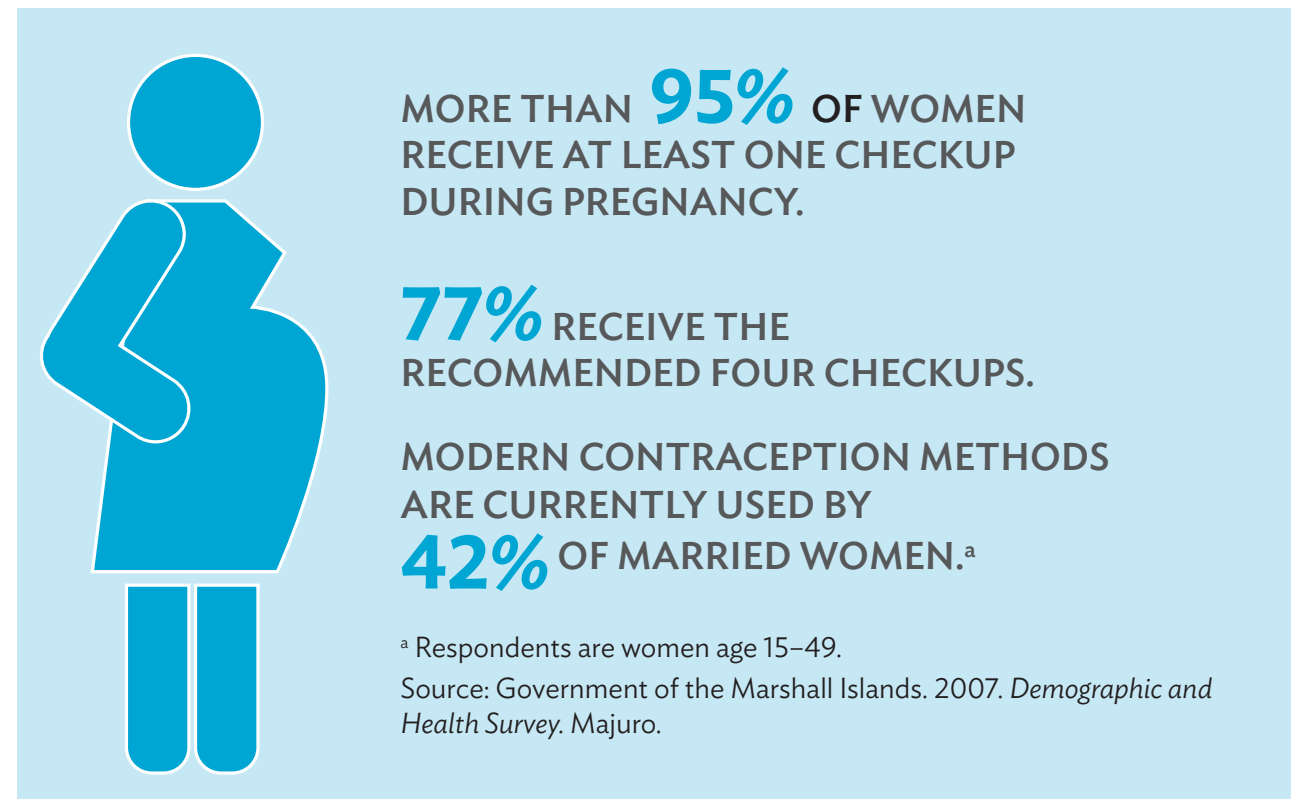

Table 5: Main Causes of Death in the Marshall Islands, 2016

\begin{tabular}{|l|c|c|}
\hline \multicolumn{1}{|c|}{ Main causes of death } & \multicolumn{2}{c|}{ Number } \\
\hline Diabetes related & Male & Female \\
Cardiovascular disease & 63 & 46 \\
Cancer (all types) & 39 & 17 \\
Hepatitis B & 14 & 18 \\
Injury/accident/drowning & 16 & 9 \\
\hline
\end{tabular}

Source: Ministry of Health.

High rates of teenage pregnancy is a key gender issue

Figure 16: Teenage Mothers as Percentage of All Registered Births, 2008-2016

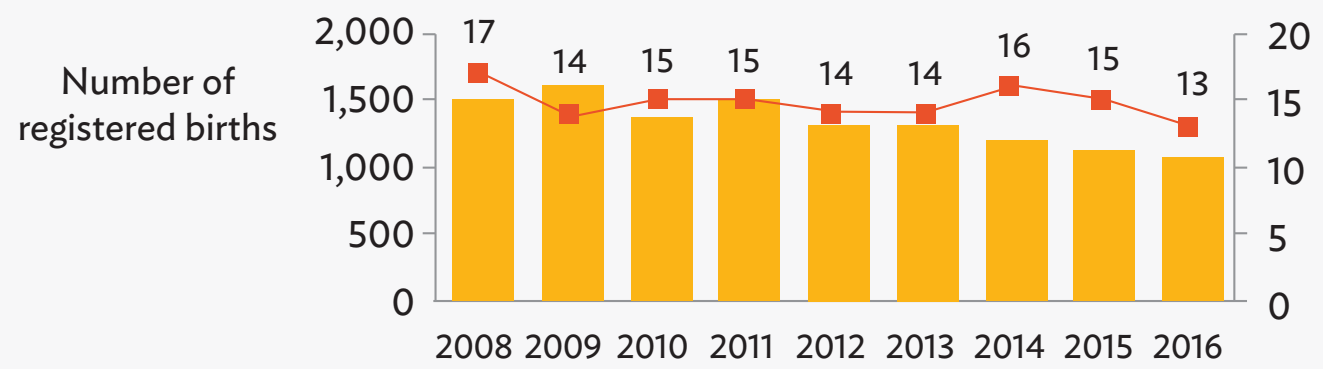

Total number of registered births $\rightarrow-\%$ of births to teenage mothers ${ }^{a}$

a Teenage mothers are defined as all mothers age 19 or younger.

Source: Government of the Marshall Islands. 2012. Ministry of Health Annual Report 2012. Majuro. 


\section{Lack of sanitation remains an issue}

Figure 17: Percentage of Households with Access to Decent Water and Sanitation, 2007

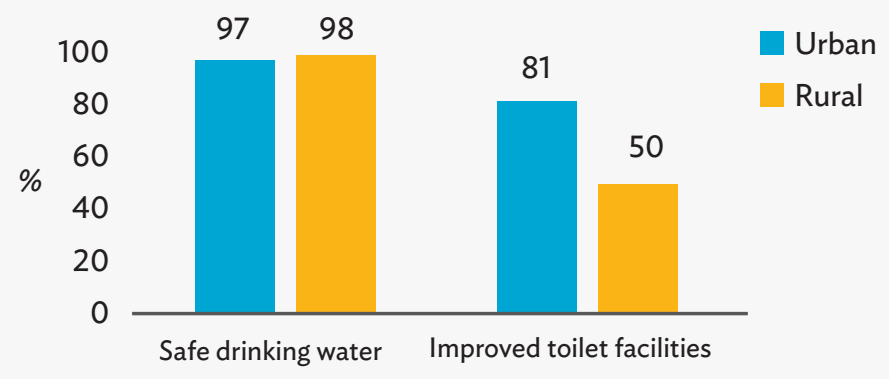

Source: Government of the Marshall Islands. 2007. Demographic and Health Survey. Majuro.

\section{Malnourished children are more likely to be from the rural poor}

Figure 18: Percentage of Children Age 0-5 Who Are Malnourished Based on Assessment of Thinness and Swelling of Feet, 2007

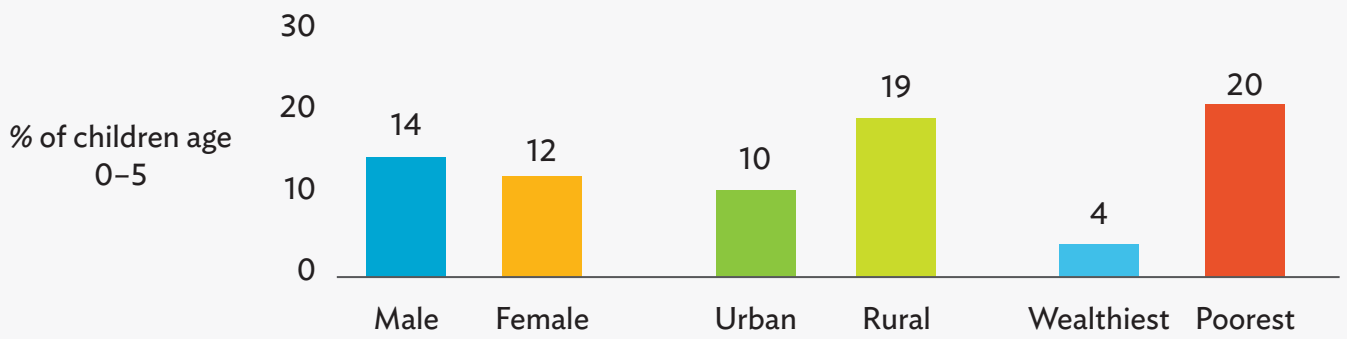

Source: Government of the Marshall Islands. 2007. Demographic and Health Survey. Majuro.

\section{Steady rates of international adoption}

Figure 19: Number of Marshall Islands Children Adopted Overseas, by Sex, 2010-2017

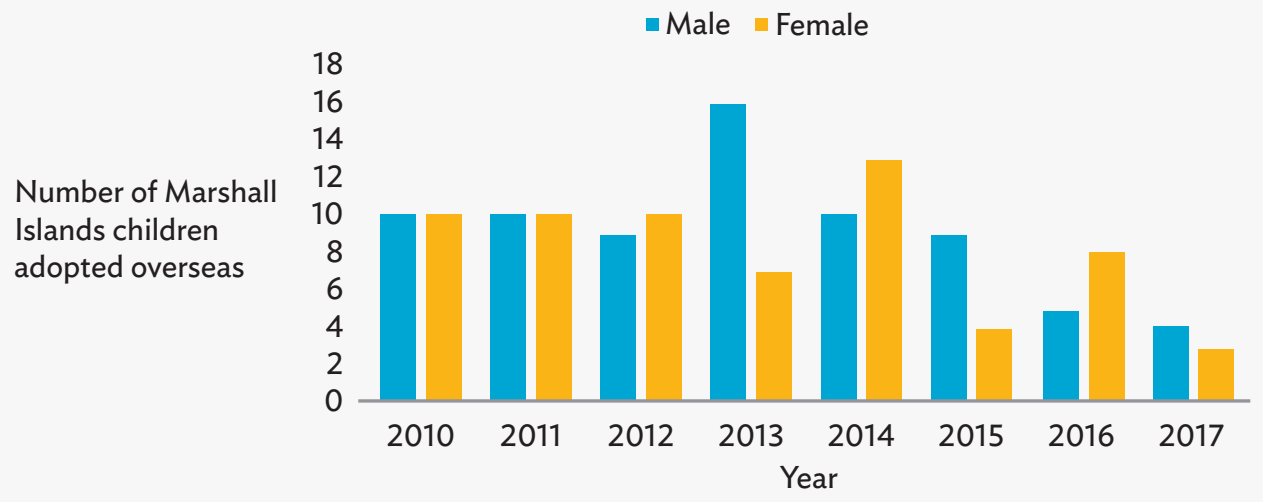

Source: Ministry of Internal Affairs. 


\section{One in 10 people has a disability}

Figure 20: Prevalence of Disability, by Sex and Number of Disabilities, 2011

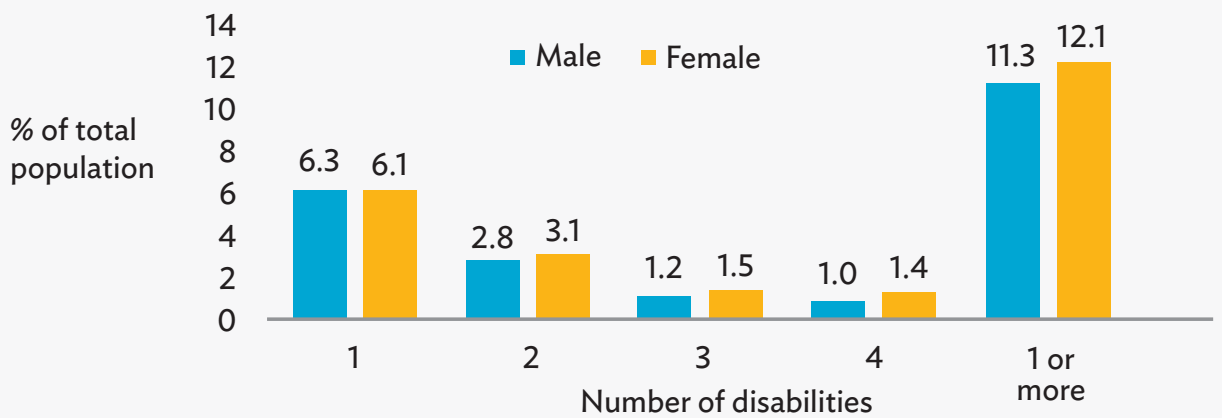

Note: The proportion of people with a disability is based on reporting about each individual's ability to see, hear, walk, or climb stairs, and/or remember/concentrate. The questions about these four domains of functioning were based on the Washington Group on Disability Statistics (http://www.washingtongroup-disability.com/washington-group-question-sets/short-set-ofdisability-questions/) international recommendations for a short set of questions to determine disability status.

Source: Government of the Marshall Islands. 2011. Republic of the Marshall Islands 2011 Census Report. Majuro.

\section{Work and Employment}

There are many types of work, both paid and unpaid, that are providing a valuable contribution to the economy.

Work involved in producing goods (e.g., vegetables, fish) for own consumption or for sale, is counted as employment and part of GDP.

However, unpaid household, community and family care work-work typically done by women - are not considered employment, or counted in the GDP. Excluded from statistics, the essential nature of this work and its contribution to the economy are often undervalued.

\section{About half of men are employed, compared with only a quarter of women}

Figure 21: Economic Activity Status of Population Age 15+, by Sex, 2011

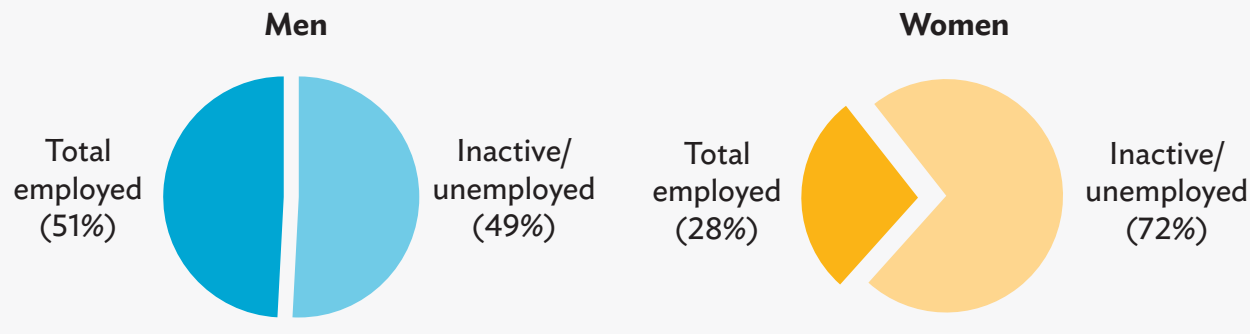




\section{Gender gaps in employment persist across age groups in both urban and rural areas}

Figure 22: Employment-to-Population Ratio in Urban Areas, by Age Group, 2011

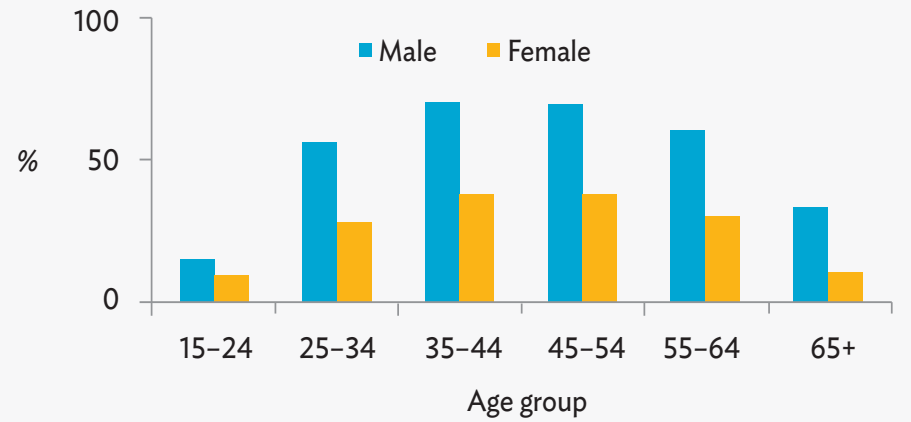

Source: Government of the Marshall Islands. 2011. Republic of the Marshall Islands 2011 Census Report. Majuro.

Figure 23: Employment-to-Population Ratio in Rural Areas, by Age Group, 2011

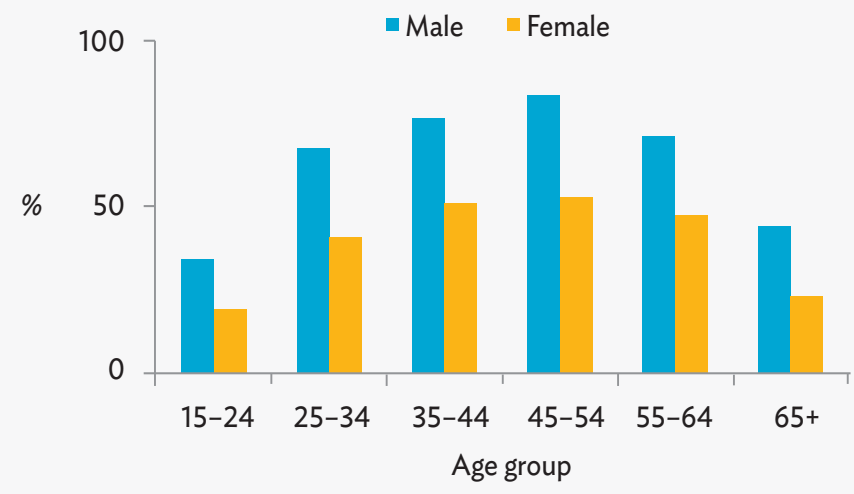

Source: Government of the Marshall Islands. 2011. Republic of the Marshall Islands 2011 Census Report. Majuro.

Table 6: Data on Employment- and Unemployment-to-Population Ratio, Marshall Islands, 2011

\begin{tabular}{|l|c|c|c|c|c|c|c|}
\hline & \multicolumn{3}{|c|}{ Marshall Islands } & \multicolumn{2}{c|}{ Urban } & Rural \\
\hline \multicolumn{1}{|c|}{ Key Indicators, 2011 } & Male & Female & Total & Male & Female & Male & Female \\
\hline Employment-to-population ratio (\%) & 51.0 & 28.0 & 39.6 & 47.4 & 24.9 & 62.2 & 38.3 \\
Paid employment-to-population ratio (\%) & 48.0 & 26.5 & 37.4 & 45.8 & 23.7 & 54.9 & 35.7 \\
Unemployment rate (\%) & n.a & n.a & n.a & 27.0 & 39.4 & n.a & n.a \\
Population doing home duties as main activity (\%) & n.a & n.a & n.a & 0.9 & 20.6 & n.a & n.a
\end{tabular}

n.a. $=$ not available.

a Data are from 2012 Labor Force Survey conducted in Majuro and the island of Ebeye (sample size: 6,841 respondents).

Sources: Government of the Marshall Islands. 2011. Republic of the Marshall Islands 2011 Census Report. Majuro; and Government of the Marshall Islands. 2012. Labor Force Survey. Majuro. 
More women are producing goods for sale, while men are more likely to be public or private sector employees

Figure 24: Employment Status of Population Age 15+, by Sex, 2011

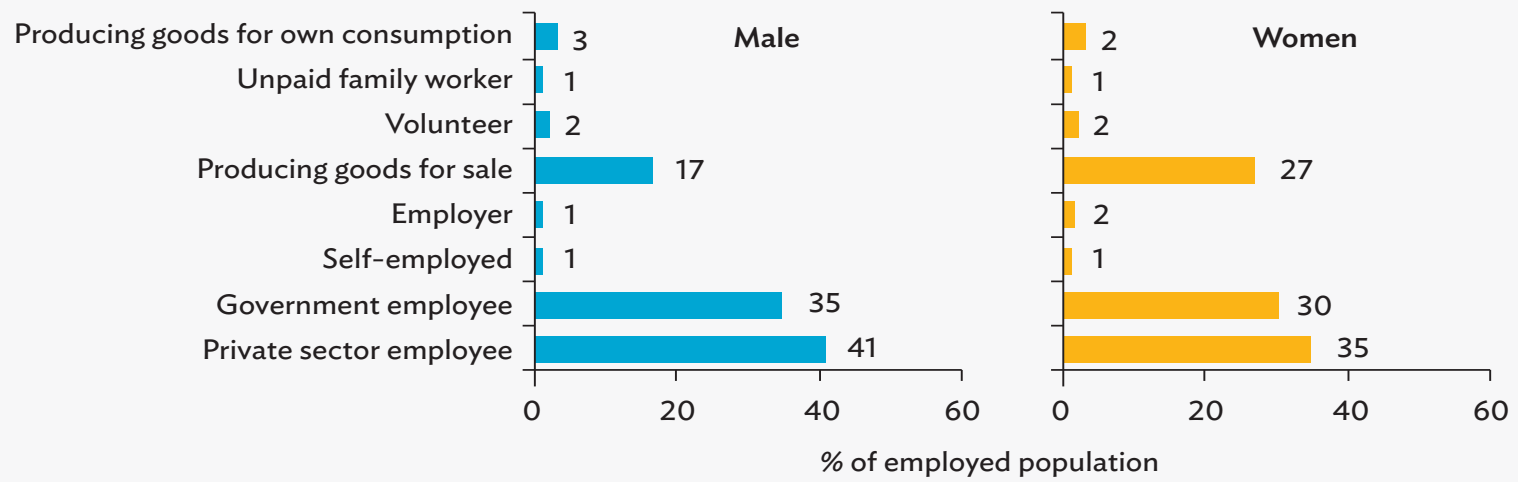

Source: Government of the Marshall Islands. 2011. Republic of the Marshall Islands 2011 Census Report. Majuro.

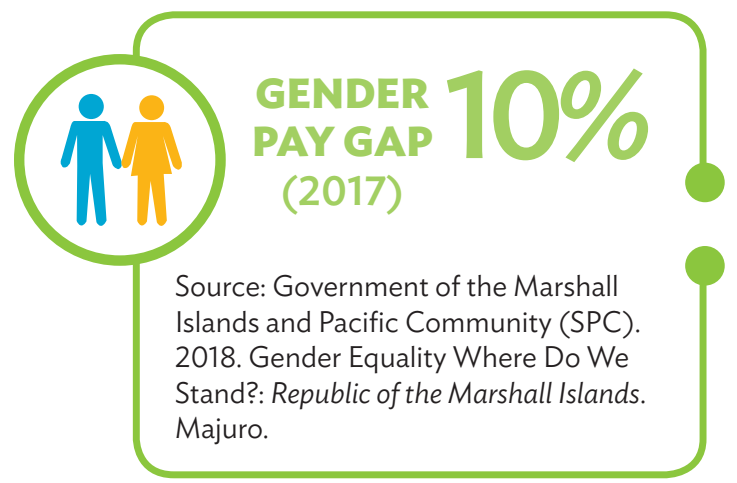

Income levels are highest in Kwajalein for both men and women

Figure 25: Average Annual Income Population Age 15+, by Sex and Island and Atoll, 2011 (\$)

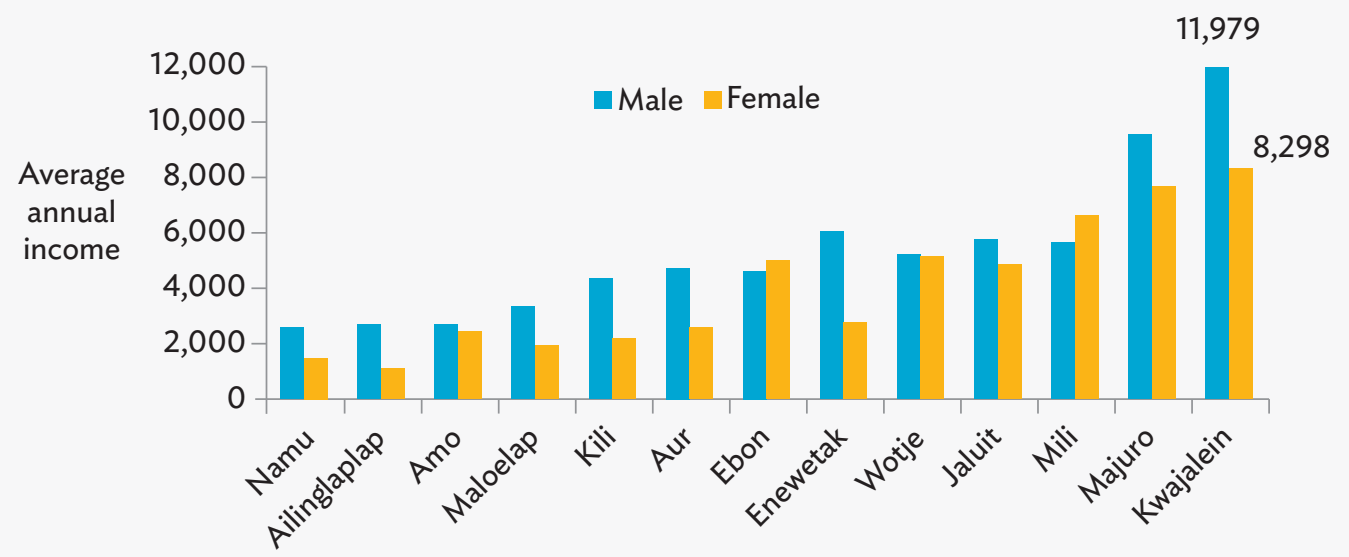

Source: Government of the Marshall Islands. 2011. Republic of the Marshall Islands 2011 Census Report. Majuro. 
Most paid employment is in the services sector

Figure 26: Share of Women in Paid Employment, Population Age 15+, by Sector and Sex, 2011

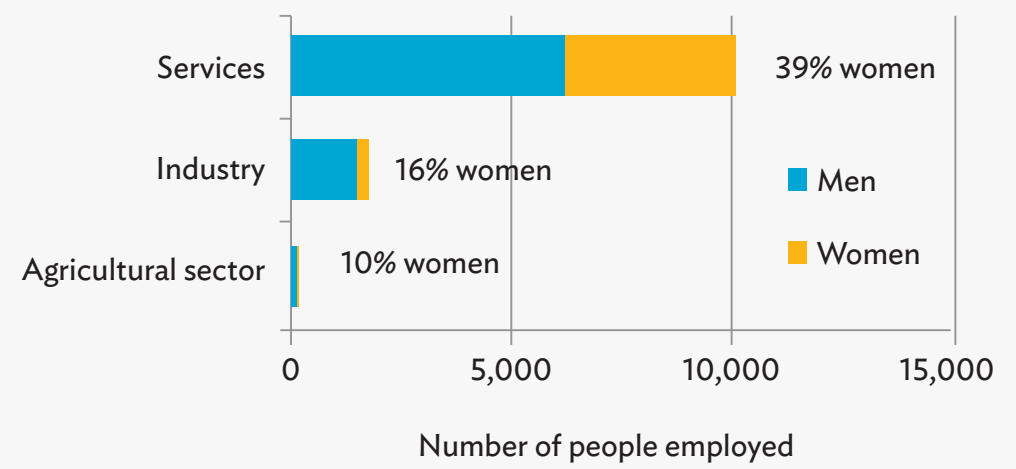

Source: Government of the Marshall Islands. 2011. Republic of the Marshall Islands 2011

Census Report. Majuro.
$35.1 \%$

WOMEN'S

SHARE OF WAGE

EMPLOYMENT IN

NON-AGRICULTURE

SECTOR (2011)

\section{Gender-Based Violence, Public Safety, and Human Rights}

Everyone has a right to live in a safe environment that is free from violence. Violence and public safety are gendered issues, with significant disparities in the perpetrators of various crimes (predominantly men), and in the making and enforcement of laws.

\section{Most police arrests are men}

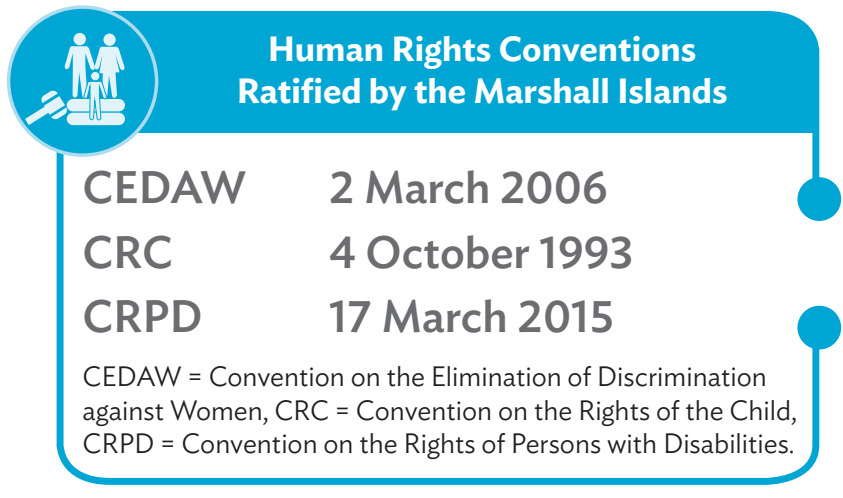

Figure 27: Number of Persons Arrested, by Sex, 2010-2016

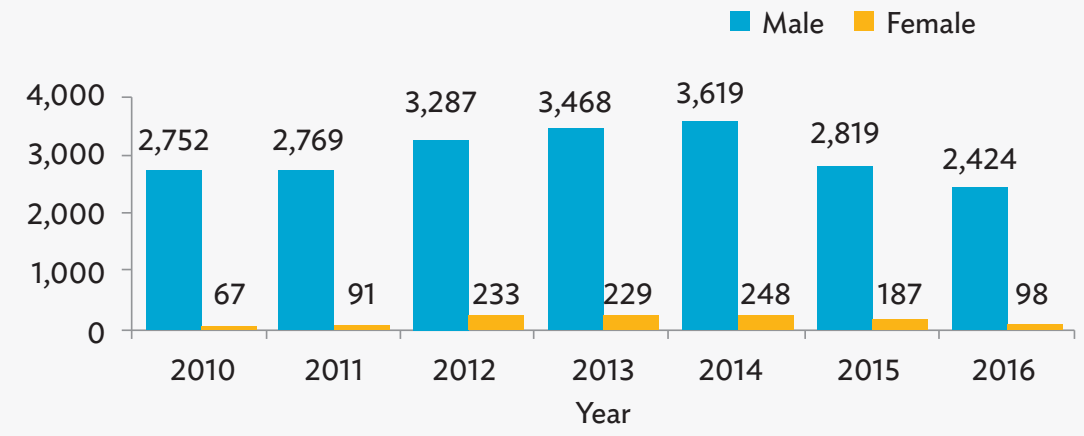

Note: Only data on the number of arrests provided.

Source: Marshall Islands Police Department. 
Few women are in the police force, which limits the access of women to a woman police officer where preferred

Table 7: Number of Police Officers, by Sex and Police Force, 2017

\begin{tabular}{l|c|c} 
& Men & Women \\
Marshall Islands National Police & 164 & 11 \\
Majuro Local Police & 101 & 5 \\
Ebeye Local Police & 52 & 4 \\
\hline
\end{tabular}

Sources: Majuro Police and Ebeye Police.

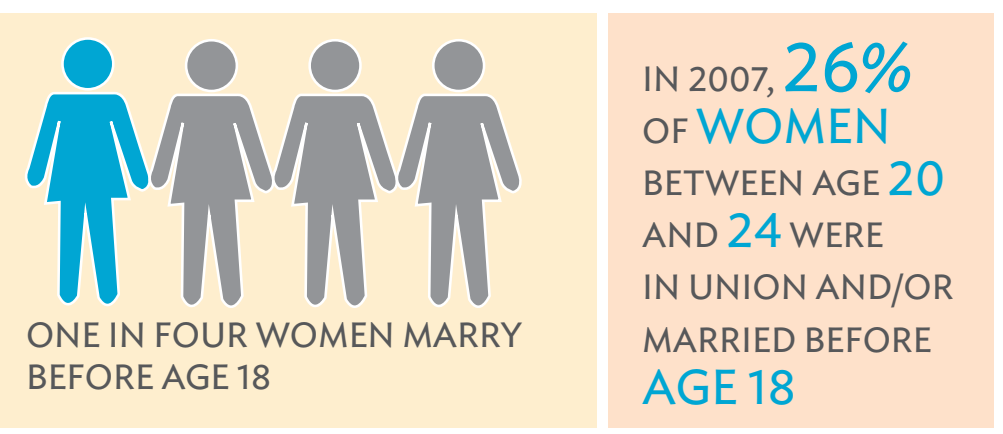

Source: 2007 Demographic and Health Survey, Government of the Marshall Islands.

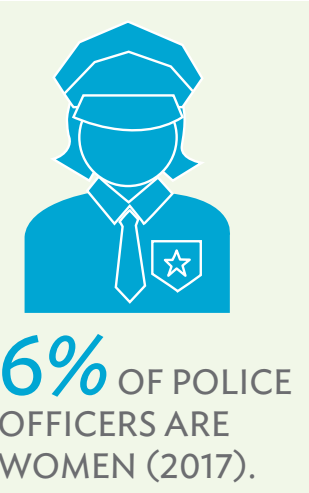

Early marriage is a deprivation of human rights. Eliminating this practice is one of the global goals for achieving gender equality and sustainable development. Women who marry as girls, before the age of 18 , tend to miss out on education and face greater health risks for themselves and their children if they start childbearing in adolescence.

\section{Women are more likely than men to marry at very young ages}

Figure 28: Number of Persons in Union/Married, by Age and Sex, 2011

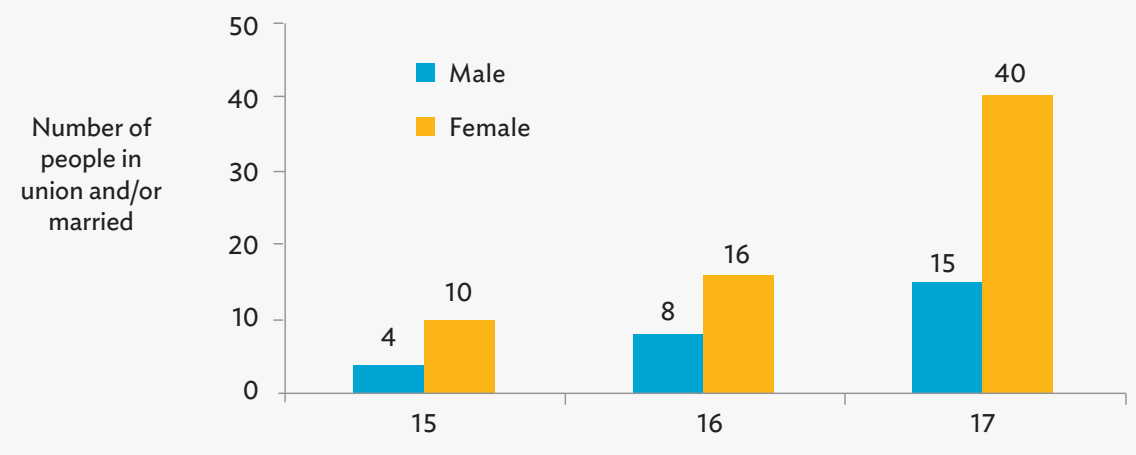

Note: The legal age for marriage is 18 years for men and women (2011).

Source: Government of the Marshall Islands. 2011. Republic of the Marshall Islands 2011 Census Report. Majuro. 
The majority of women in relationships have experienced some form of violence by their partners

Figure 29: Prevalence of Intimate Partner Violence among Ever-Partnered Women, 2012

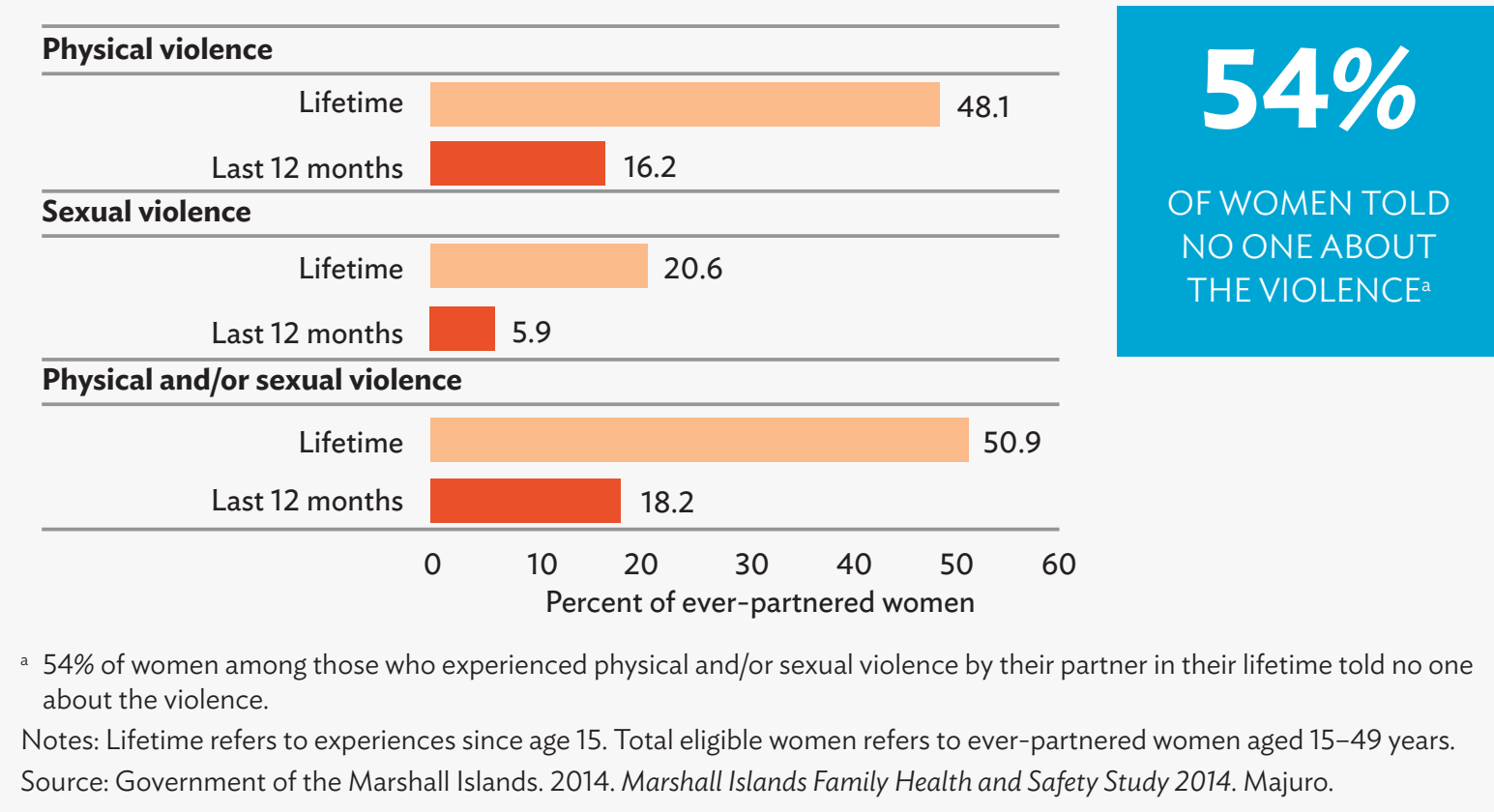

\section{Political Participation and Decision-Making}

The head of state and government is the President. Marshall Islands has a bicameral parliament comprising the Council of Iroji (upper house) of 12 appointed tribal chiefs, and the Nitijela (lower house) of 33 elected senators. There are local governments in the 24 main islands and atolls. They each have an elected council, mayor, appointed local officials, and a local police force. The latest official statistics are for 2011, when 3 of the 24 mayors (13\%) and 47 of the 251 councillors (19\%) were women.

\section{Two women are in Parliament}

Figure 30: Share of Parliamentary Seats, by Sex, 2020

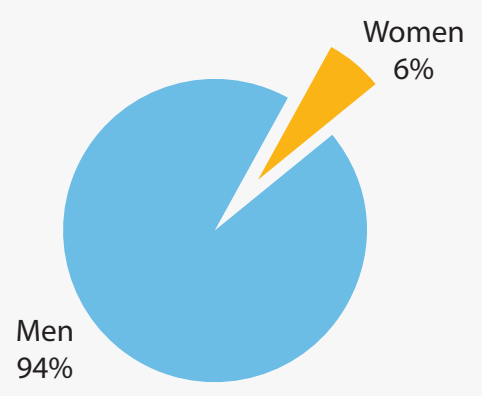

Source: Marshall Islands Parliament. 
Few of the judges are women

Figure 31: Number of Judges in the Marshall Islands Judiciary, by Sex (2010-2017)

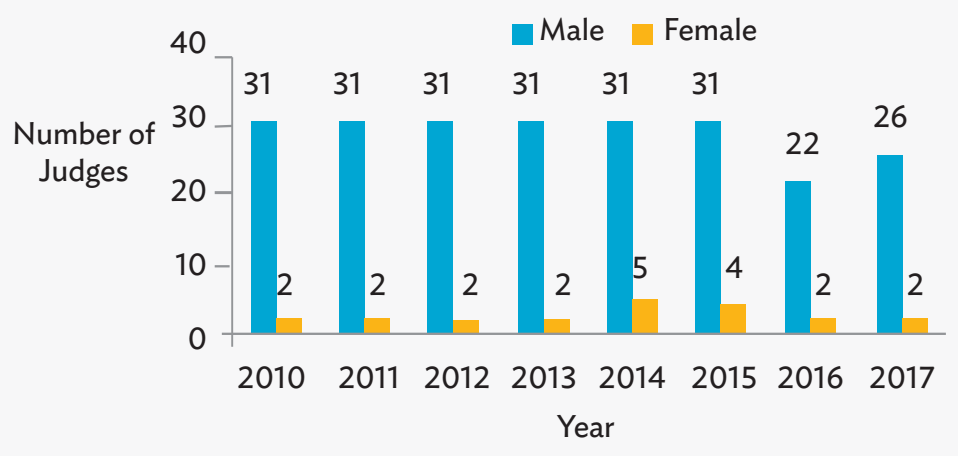

Sources: Marshall Islands courts.

Figure 32: Proportion of Women in the National Parliament, 2019

Nitijela, the lower house, has 33 elected senators (2020)

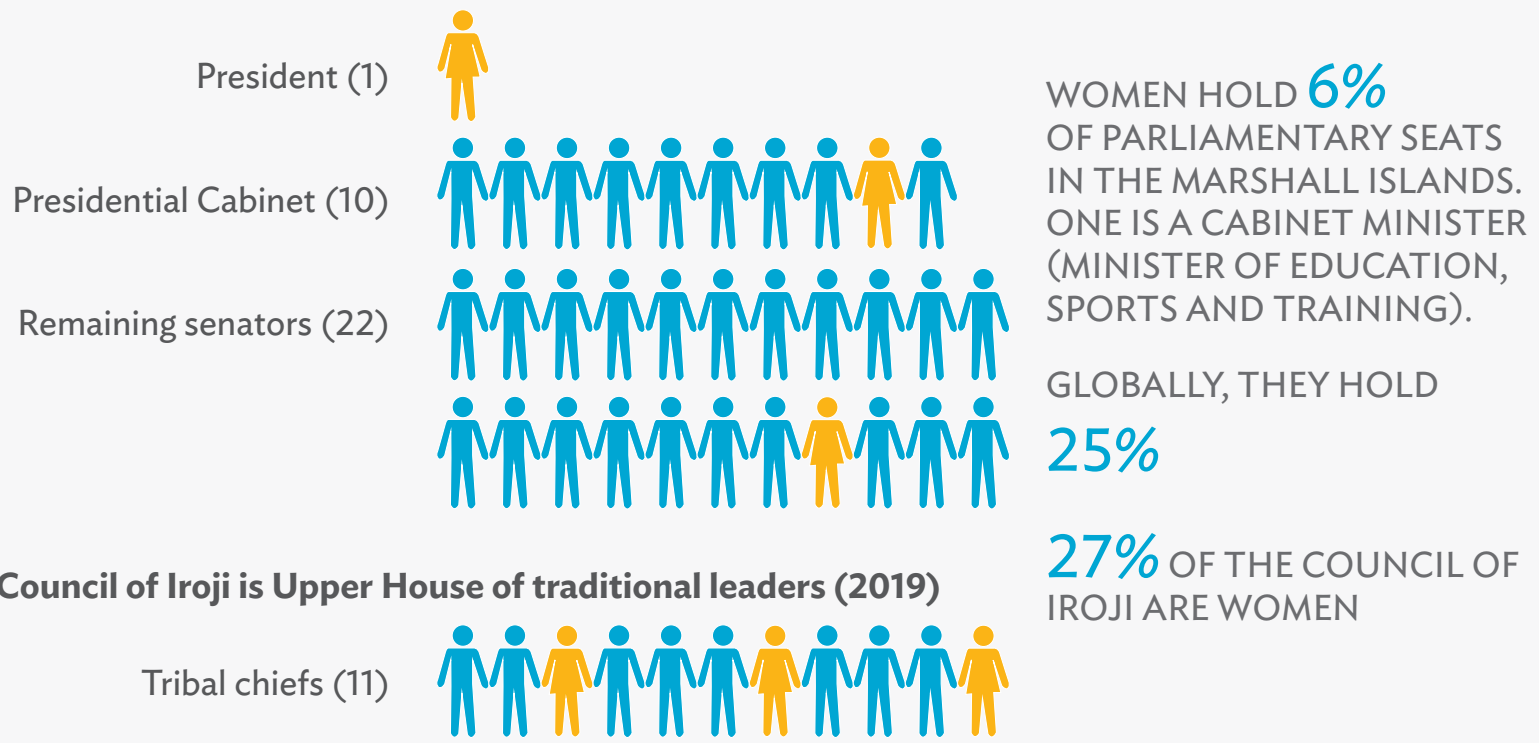

Sources: Marshall Islands courts (rmicourts.org/the_judiciary.html); Embassy of the Marshall Islands in the United States (www.rmiembassyus.org/Government.htm); and Secretariat of the Pacific Community. 2012. Stocktake of the Gender Mainstreaming Capacity of Pacific Island Governments: Republic of the Marshall Islands. Noumea. 


\section{Environment and Climate Change}

Gender is an important factor in managing the environment. Women and men have varying degrees of access to and control of natural resources, and environmental policies and initiatives need to take this into account.

There are strong commitments and action to meet the outcomes of the Sendai Framework for action while risks remain high. These are guided by the 2011 National Climate Change Policy and 2014-2018 Joint National Action Plan on Climate Change Adaptation and Disaster Risk Management. Included as an aim is stronger genderspecific monitoring.

\section{The Marshall Islands ranks ninth in the Pacific island countries in protecting land and marine resources.}

Land and marine resources are threatened by numerous factors, including overfishing, coastal habitat degradation, population density, and pollution from a wide range of sources. The government is actively engaged in a range of initiatives in response."1

Table 8: Ranking of Pacific Island Countries by the Proportion of Land and Marine (Exclusive Economic Zone) Area Under Protection, 2015

\begin{tabular}{|c|c|c|c|}
\hline $\begin{array}{l}\text { Ranking (most-to least- } \\
\text { protected area) }\end{array}$ & Country & Land Area $\left(\mathrm{km}^{2}\right)$ & $E E Z\left(k m^{2}\right)^{a}$ \\
\hline 1 & New Caledonia & 18,576 & $1,740,000$ \\
\hline 2 & Northern Mariana Islands & 457 & $1,823,000$ \\
\hline 3 & Kiribati & 811 & $3,550,000$ \\
\hline 4 & American Samoa & 199 & 390,000 \\
\hline 5 & Tonga & 650 & 700,000 \\
\hline 6 & Fiji & 18,273 & $1,290,000$ \\
\hline 7 & Papua New Guinea & 462,840 & $2,446,757$ \\
\hline 8 & Palau & 444 & 629,000 \\
\hline 9 & Marshall Islands & 181 & $2,131,000$ \\
\hline 10 & Samoa & 2,935 & 120,000 \\
\hline 11 & Solomon Islands & 30,407 & $1,340,000$ \\
\hline 12 & Vanuatu & 12,281 & 680,000 \\
\hline 13 & Guam & 541 & 218,000 \\
\hline 14 & Federated States of Micronesia & 701 & $2,978,000$ \\
\hline 15 & Nive & 259 & 390,000 \\
\hline 16 & Tuvalu & 26 & 900,000 \\
\hline 17 & French Polynesia & 3,521 & $5,030,000$ \\
\hline 18 & Tokelau & 12 & 290,000 \\
\hline 19 & Cook Islands & 237 & $1,830,000$ \\
\hline 20 & Wallis and Futuna & 142 & 300,000 \\
\hline
\end{tabular}

$\mathrm{EEZ}=$ exclusive economic zone, $\mathrm{km}^{2}$ = square kilometer.

a The EEZ is the ocean area surrounding Pacific island states in which they have exclusive rights to exploit their natural resources. Sources: Rankings are based on the sum of protected areas listed in the World Database on Protected Areas as of 3 September 2015 (www.protectedplanet.net/) divided by total land and marine area; World Bank. 2014. Pacific Islands Regional Oceanscape Program. Washington, DC; and Baker et al. 2011. Reimaanlok: A National Framework for Conservation Area Planning in the Marshall Islands. Journal of Marine Biology.

1 Center for Excellence in Disaster Management and Humanitarian Assistance. 2016. The Republic of the Marshall Islands: Disaster Management Reference Book. Majuro. 
Table 9: Major Weather Events, 1979-2019

\begin{tabular}{|c|c|c|}
\hline Year & Type of Event & Area(s) Affected \\
\hline $\begin{array}{l}2015- \\
2017\end{array}$ & Extreme drought & All of the Marshall Islands (declared a national disaster) \\
\hline 2015 & Typhoon Nangka & Majuro, Enewetak, Wotje, and Wotho \\
\hline 2014 & Sea swell/king tide & $\begin{array}{l}\text { Arno, Kili, Maloelap, Majuro, Mili, and Wotje State of Emergency } \\
\text { declared }\end{array}$ \\
\hline 2013 & Drought & 15 atolls/islands north of Majuro (above $8^{\circ} \mathrm{N}$ latitude) \\
\hline 2013 & Sea swell/king tide & Majuro \\
\hline 2008 & Sea swell/king tide & Numerous Pacific locations, including the Marshall Islands \\
\hline 2008 & State of Economic Emergency & All of the Marshall Islands \\
\hline 2007 & Severe drought & Majuro, Utrik, Wotho, Lae, Namu, and Ailuk \\
\hline 1998 & Severe drought & All of the Marshall Islands \\
\hline 1997 & Typhoon Paka & Majuro, Ailinglaplap, and Namu \\
\hline 1994 & High surf/wave action & Ajeltake in Majuro \\
\hline 1992 & Tropical Storm Axel & All of the Marshall Islands \\
\hline 1991 & Typhoon Zelda & All of the Marshall Islands \\
\hline 1988 & Tropical Storm Roy & Kwajalein \\
\hline 1979 & Sea swell & Majuro \\
\hline
\end{tabular}

Source: Center for Excellence in Disaster Management and Humanitarian Assistance. 2019. Republic of the Marshall Islands Disaster Management Reference Handbook. Hawaii. 


\section{APPENDIX \\ SUSTAINABLE DEVELOPMENT GOALS- DATA SOURCES AND AVAILABILITY}

Many of the 240 Sustainable Development Goals (SDGs) indicators require disaggregation by sex or relate to gender issues, such as maternal health and violence against women and girls. The table below summarizes which indicators are considered to be gender-related under each goal and their tier status $(1,2$, or 3$)$ as of 26 September 2019. ${ }^{1}$ Tier 3 indicators are those for which standard definitions and methodology are still under development at the global level.

\section{Availability of Gender-Specific and Gender-Related Sustainable Development Goal Indicators} in the Marshall Islands

\begin{tabular}{|c|c|c|c|c|c|}
\hline \multirow[b]{2}{*}{$\begin{array}{l}\text { Gender-Specific (marked with*) } \\
\text { and Gender-Related Indicator(s) }\end{array}$} & \multirow{2}{*}{$\begin{array}{l}\text { Tier Status } \\
\text { (as of } \\
26 \text { September } \\
\text { 2019) }\end{array}$} & \multicolumn{2}{|c|}{$\begin{array}{l}\text { Rapid Assessment } \\
\text { of Data Availability }\end{array}$} & \multicolumn{2}{|c|}{ Data in Global SDG Database } \\
\hline & & $\begin{array}{l}\text { Can the } \\
\text { indicator be } \\
\text { produced? }\end{array}$ & Data Source & $\begin{array}{l}\text { Currently in } \\
\text { the Global } \\
\text { Database }\end{array}$ & Notes \\
\hline $\begin{array}{l}\text { 1.1.1* Proportion of population } \\
\text { below the international poverty } \\
\text { line, by sex, age, employment status } \\
\text { and geographical location (urban } \\
\text { and/or rural) }\end{array}$ & Tier 1 & Yes & $\begin{array}{l}2002 \text { Household } \\
\text { Income and } \\
\text { Expenditure } \\
\text { Survey (HIES) }\end{array}$ & No & \\
\hline $\begin{array}{l}\text { 1.2.1* Proportion of population living } \\
\text { below the national poverty line, by } \\
\text { sex and age }\end{array}$ & Tier 1 & Yes & 2002 HIES & No & \\
\hline $\begin{array}{l}\text { 1.2.2* Proportion of men, women, } \\
\text { and children of all ages living in } \\
\text { poverty in all its dimensions } \\
\text { according to national definitions }\end{array}$ & Tier 2 & Yes & 2002 HIES & No & \\
\hline $\begin{array}{l}\text { 1.3.1* Proportion of population } \\
\text { covered by social protection floors/ } \\
\text { systems, by sex, distinguishing } \\
\text { children, unemployed persons, older } \\
\text { persons, persons with disabilities, } \\
\text { pregnant women, newborns, work- } \\
\text { injury victims, and the poor and the } \\
\text { vulnerable }\end{array}$ & Tier 2 & No & & Yes & $\begin{array}{l}\text { For older persons } \\
\text { only and not } \\
\text { sex-disaggregated } \\
\text { (International } \\
\text { Labour } \\
\text { Organization } \\
\text { [ILO]) }\end{array}$ \\
\hline
\end{tabular}

continued on next page 
Appendix table continued

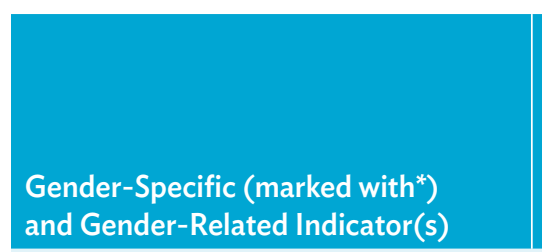

1.4.2* Proportion of total adult population with secure tenure rights to land, with legally recognized documentation and who perceive their rights to land as secure, by sex and by type of tenure

1.5.1 Number of deaths, missing persons, and directly affected persons attributed to disasters, per 100,000 people

1.b.1* Proportion of government recurrent and capital spending to sectors that disproportionately benefit women, the poor, and vulnerable groups

2.1.2. Prevalence of moderate or severe food insecurity in the population, based on the Food Insecurity Experience Scale (FIES)

2.2.1 Prevalence of stunting (height for age $<-2$ standard deviation from the median of the World Health Organization (WHO) Child Growth Standards) among children under 5 years of age

2.2.2 Prevalence of malnutrition (weight for height $>+2$ or $<-2$ standard deviation from the median of the WHO Child Growth Standards) among children under 5 years of age

\subsection{2* Average income of small-} scale food producers, by sex and indigenous status

\subsection{1* Maternal mortality ratio}

3.1.2* Proportion of births attended by skilled health personnel

Tier $1 \quad$ Yes

3.2.1 Under-5 mortality rate

3.3.1* Number of new HIV infections per 1,000 uninfected population, by sex, age, and key populations

Tier Status
(as of
26 September
2019)

Tier 2
Tier 2

No

Tier $1 \quad$ Yes
Rapid Assessment of Data Availability

Can the

indicator be produced?

No

\section{Data in Global SDG Database ${ }^{a}$}

Currently in

the Global

Data Source Database

Notes

\begin{tabular}{|c|c|c|c|c|}
\hline Tier 2 & Yes & $\begin{array}{l}\text { National Disaster } \\
\text { Management } \\
\text { Office }\end{array}$ & Yes & $\begin{array}{l}\text { (United Nations } \\
\text { Office for Disaster } \\
\text { Risk Reduction } \\
\text { [UNISDR]) }\end{array}$ \\
\hline
\end{tabular}

Tier 3

No

\begin{tabular}{|c|c|c|}
\hline Tier 2 & Yes & $\begin{array}{l}2017 \text { Integrated } \\
\text { Child Nutrition } \\
\text { and Health } \\
\text { Survey }\end{array}$ \\
\hline Tier 1 & Yes & $\begin{array}{l}2017 \text { Integrated } \\
\text { Child Nutrition } \\
\text { and Health } \\
\text { Survey }\end{array}$ \\
\hline
\end{tabular}

Tier $1 \quad$ Yes 2017 Integrated Yes

Child Nutrition and Health Survey

No

2011 Census and Ministry of Health records

No 
Appendix table continued

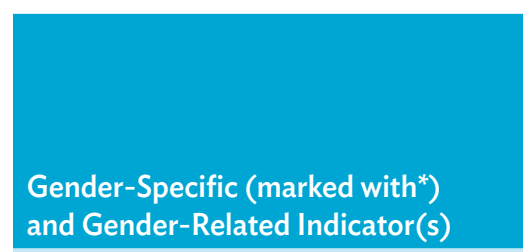

3.4.1 Mortality rate attributed to cardiovascular disease, cancer, diabetes, or chronic respiratory disease

3.4.2 Suicide mortality rate

3.5.2 Harmful use of alcohol, defined according to the national context as alcohol per capita consumption (age 15 years and older) within a calendar year, in liters of pure alcohol

3.6.1 Death rate due to road traffic injuries

3.7.1* Proportion of women of reproductive age (age 15-49 years) who have their need for family planning satisfied with modern methods

\subsection{2* Adolescent birth rate}

(age 10-14 years; aged $15-19$ years) per 1,000 women in that age group

3.8.1 Coverage of essential health services (defined as the average coverage of essential services based on tracer interventions that include reproductive, maternal, newborn and child health, infectious diseases, noncommunicable diseases, and service capacity and access, among the general and the most disadvantaged population)

3.8.2 Proportion of population with large household expenditures on health as a share of total household expenditure or income

3.9.1 Mortality rate attributed to household and ambient air pollution

3.9.2 Mortality rate attributed to unsafe water, unsafe sanitation, and lack of hygiene (exposure to unsafe Water, Sanitation and Hygiene for All [WASH] services)

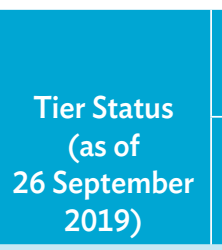

\begin{tabular}{|c|}
\hline $\begin{array}{c}\text { Rapid Ass } \\
\text { of Data } A\end{array}$ \\
\hline $\begin{array}{c}\text { Can the } \\
\text { indicator be } \\
\text { produced? }\end{array}$ \\
\hline
\end{tabular}

Tier 1 Yes

Tier 1

Yes

Ministry of

No

Health

Tier 1

No

No

Ministry of No

Health
Data in Global SDG Database ${ }^{\mathrm{a}}$

Currently in

the Global

Database

Notes

$\begin{array}{lll}\text { Tier } 1 \text { Yes } & \begin{array}{l}\text { Ministry of } \\ \text { Health }\end{array}\end{array}$

$\begin{array}{lll}\text { Tier } 1 & \text { Yes } & 2007 \\ & & \text { Demographic } \\ & \text { and Health } & \text { Yes } \\ & \text { Survey (DHS) }\end{array}$

$\begin{array}{lll}\text { Tier } 1 & \text { Yes } & 2011 \text { Census }\end{array}$

$\begin{array}{lll}\text { Tier } 1 & \text { Yes } & \text { Produced by } \\ & \text { WHO Western } & \text { No }\end{array}$

Pacific Region

$\begin{array}{lll}\text { Tier } 1 & \text { Yes } & 2002 \text { HIES No }\end{array}$

continued on next page 
Appendix table continued

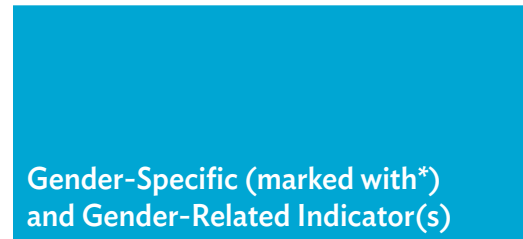

3.a.1 Age-standardized prevalence of current tobacco use among persons aged 15 years and older

3.b.1 Proportion of the target population covered by all vaccines included in their national programme

4.1.1* Proportion of children and young people: (a) in grades $2 / 3$; (b) at the end of primary; and (c) at the end of lower secondary achieving at least a minimum proficiency level in (i) reading and (ii) mathematics, by sex

4.2.1* Proportion of children under 5 years of age who are developmentally on track in health, learning and psychosocial well-being, by sex

4.2.2* Participation rate in organized learning (one year before the official primary entry age), by sex

4.3.1* Participation rate of youth and adults in formal and non-formal education and training in the last 12 months, by sex

4.4.1 Proportion of youth and adults with information and communications technology (ICT) skills, by type of skill

4.5.1* Parity indices (female/male rural/urban, bottom/top wealth quintile and others such as disability status, indigenous peoples and conflict-affected, as data become available) for all education indicators on this list that can be disaggregated

4.6.1* Percentage of population in a given age group achieving at least a fixed level of proficiency in functional (a) literacy and (b) numeracy skills, by sex

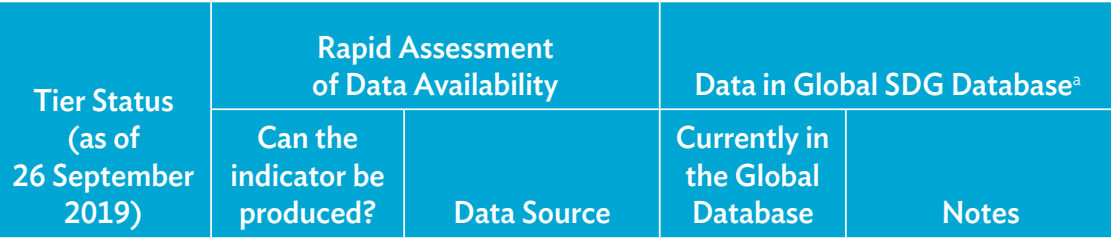

Tier 1 Yes 2011 Census No

Tier 1 Yes Ministry of Yes

Health

Tier 2 Yes Ministry of No

Education

$\begin{array}{lll}\text { Tier } 2 & \text { Yes } & \begin{array}{l}\text { Ministry of } \\ \text { Education }\end{array}\end{array}$

$\begin{array}{lll}\text { Tier } 1 & \text { Yes } & \text { Ministry of }\end{array}$

Education

Tier $2 \quad$ No

No

Tier 2

No

No

$\begin{array}{lll}\text { Tiers 1,2 and } & \text { Yes } & \begin{array}{l}\text { Ministry of } \\ \text { Education }\end{array} \\ \begin{array}{c}3 \text { depending } \\ \text { on indice }\end{array} & & \text { Yes }\end{array}$

Tier 2

No

No 
Appendix table continued

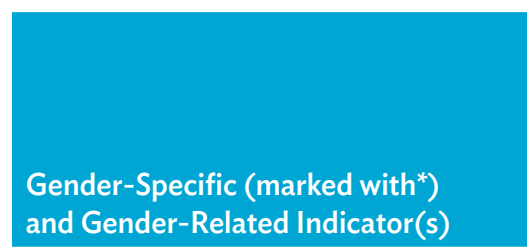

4.7.1* Extent to which (i) global citizenship education; and (ii) education for sustainable development, including gender equality and human rights, are mainstreamed at all levels in:

(a) national education policies,

(b) curricula, (c) teacher education, and (d) student assessment

4.a.1* Proportion of schools with access to (a) electricity, (b) the internet for pedagogical purposes, (c) computers for pedagogical purposes, (d) adapted infrastructure and materials for students with disabilities, (e) basic drinking water, (f) single-sex basic sanitation facilities, and ( $g$ ) basic handwashing facilities (as defined in WASH indicators)

\subsection{1* Whether or not legal}

frameworks are in place to promote, enforce, and monitor equality and nondiscrimination on the basis of sex

5.2.1* Proportion of ever-partnered women and girls age 15 years and older subjected to physical, sexual, or psychological violence by a current or former intimate partner in the previous 12 months, by form of violence and by age

\subsection{2* Proportion of women and} girls age 15 years and older subjected to sexual violence by persons other than an intimate partner in the previous 12 months, by age and place of occurrence

5.3.1* Proportion of women age 20-24 years who were married or in a union before age 15 and before age 18

5.3.2 Proportion of girls and women age $15-49$ years who have undergone female genital mutilation/cutting, by age

\begin{tabular}{|c|c|c|c|c|}
\multirow{4}{*}{$\begin{array}{c}\text { Tier Status } \\
\text { (as of }\end{array}$} & \multicolumn{2}{|c|}{$\begin{array}{c}\text { Rapid Assessment } \\
\text { of Data Availability }\end{array}$} & \multicolumn{2}{|c}{ Data in Global SDG Database $^{\text {a }}$} \\
\cline { 2 - 4 } $\begin{array}{c}\text { 26 September } \\
\text { 2019) }\end{array}$ & $\begin{array}{c}\text { Can the } \\
\text { indicator be } \\
\text { produced? }\end{array}$ & Data Source & $\begin{array}{c}\text { Currently in } \\
\text { the Global } \\
\text { Database }\end{array}$ & Notes \\
\hline
\end{tabular}

Tier 3

No

$\begin{array}{lll}\text { Tier } 2 \text { Yes } & \begin{array}{l}\text { Ministry of } \\ \text { Education }\end{array}\end{array}$

$\begin{array}{lll}\text { Tier } 2 & \text { Yes } & \text { Ministry of } \\ & \text { Internal Affairs }\end{array}$

$\begin{array}{lll}\text { Tier } 2 & \text { Yes } & \text { 2012 Family } \\ & \text { Health and } & \text { Yes } \\ & \text { Safety Study }\end{array}$

$\begin{array}{lll}\text { Tier } 2 & \text { Yes } & \text { 2012 Family } \\ & \text { Health and } \\ & \text { Safety Study }\end{array}$

$\begin{array}{lll}\text { Tier } 1 & \text { Yes } & 2007 \text { DHS }\end{array}$

Tier 1

No 
Appendix table continued

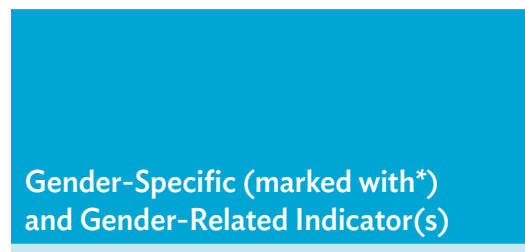

5.4.1* Proportion of time spent on unpaid domestic and care work, by sex, age, and location

5.5.1* Proportion of seats held by women in (a) national parliaments and (b) local governments

\subsection{2* Proportion of women in managerial positions}

5.6.1* Proportion of women age 15-49 years who make their own informed decisions regarding sexual relations, contraceptive use, and reproductive health care

5.6.2* Number of countries with laws and regulations that guarantee full and equal access to women and men age 15 years and older to sexual and reproductive health care, information, and education

5.a.1* (a) Proportion of total agricultural population with ownership or secure rights over agricultural land, by sex; and (b) share of women among owners or rights-bearers of agricultural land, by type of tenure

5.a.2* Proportion of countries where the legal framework (including customary law) guarantees women's equal rights to land ownership and/ or control

5.b.1* Proportion of individuals who own a mobile telephone, by sex

5.c.1* Proportion of countries with systems to track and make public allocations for gender equality and women's empowerment

6.2.1 Proportion of population using safely managed sanitation services, including a hand-washing facility with soap and water

\begin{tabular}{c|c|c|c|c}
\multirow{2}{*}{$\begin{array}{c}\text { Tier Status } \\
\text { (as of }\end{array}$} & \multicolumn{2}{|c|}{$\begin{array}{c}\text { Rapid Assessment } \\
\text { of Data Availability }\end{array}$} & \multicolumn{2}{c}{ Data in Global SDG Database ${ }^{\text {a }}$} \\
\cline { 2 - 4 } $\begin{array}{c}\text { 26 September } \\
2019)\end{array}$ & $\begin{array}{c}\text { Can the } \\
\text { indicator be } \\
\text { produced? }\end{array}$ & Data Source & $\begin{array}{c}\text { Currently in } \\
\text { the Global } \\
\text { Database }\end{array}$ & Notes \\
\hline
\end{tabular}

Tier 2

No

No

Tier 1 (a)/ Yes Administrative Yes

Tier 2 (b) records

Tier 1 Yes 2012 Labour No

Force Survey;

2011 Census

Tier 2 No No

$\begin{array}{lll}\text { Tier } 2 \text { No No } & \text { No }\end{array}$
Ministry of No

Internal Affairs $\begin{array}{lll}\text { Tier } 2 & \text { Yes } & \begin{array}{l}\text { Ministry of } \\ \text { Internal Affairs }\end{array}\end{array}$
No

\begin{tabular}{|c|c|c|}
\hline Tier 2 & No & \\
\hline Tier 2 & Yes & $\begin{array}{l}\text { Ministry of } \\
\text { Internal Affairs }\end{array}$ \\
\hline
\end{tabular}

Tier 2 Yes 2011 Census Yes


Appendix table continued

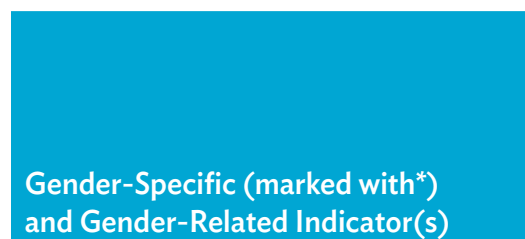

7.1.2 Proportion of population with primary reliance on clean fuels and technology

\subsection{1* Proportion of informal employment in non-agriculture employment, by sex}

8.5.1* Average hourly earnings of female and male employees, by occupation, age, and persons with disabilities

8.5.2* Unemployment rate, by sex, age, and persons with disabilities

8.6.1 Proportion of youth (age 15-24 years) not in education, employment, or training

8.7.1* Proportion and number of children age 5-17 years engaged in child labor, by sex and age

8.8.1* Frequency rates of fatal and nonfatal occupational injuries, by sex and migrant status

8.8.2* Level of national compliance with labor rights (freedom of association and collective bargaining) based on ILO textual sources and national legislation, by sex and migrant status

8.9.2 Proportion of jobs in sustainable tourism industries out of total tourism jobs

8.10.2 Proportion of adults ( 15 years and older) with an account at a bank or other financial institution or with a mobile-money-service provider

9.5.2 Researchers (in full-time equivalent) per million inhabitants

10.2.1* Proportion of people living below $50 \%$ of median income, by age, sex, and persons with disabilities

\begin{tabular}{|c|c|c|c|c|}
\hline \multirow{2}{*}{$\begin{array}{l}\text { Tier Status } \\
\text { (as of } \\
26 \text { September } \\
\text { 2019) }\end{array}$} & \multicolumn{2}{|c|}{$\begin{array}{l}\text { Rapid Assessment } \\
\text { of Data Availability }\end{array}$} & \multicolumn{2}{|c|}{ Data in Global SDG Database } \\
\hline & $\begin{array}{c}\text { Can the } \\
\text { indicator be } \\
\text { produced? }\end{array}$ & Data Source & $\begin{array}{l}\text { Currently in } \\
\text { the Global } \\
\text { Database }\end{array}$ & Notes \\
\hline Tier 1 & Yes & 2011 Census & Yes & \\
\hline
\end{tabular}

Tier 2

Yes

2012 Labour

No

Force Survey; 2011 Census

Tier 2 Yes

2012 Labour

Force Survey;

2011 Census

No

Tier $1 \quad$ Yes

2012 Labour

Force Survey

Yes

Tier $1 \quad$ Yes

2012 Labour

Force Survey

No

Tier $2 \quad$ No

No

Tier 2

No

No

Tier 2

No

No

Tier 3

No

Tier 1

No

No

Tier 1

No

No

Tier 2

Yes

2002 HIES

No 
Appendix table continued

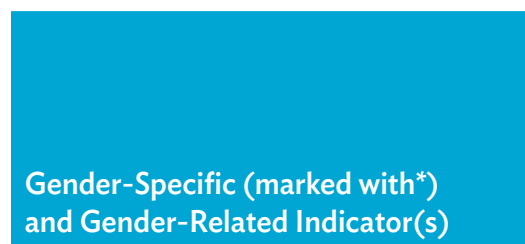

10.3.1* Proportion of population reporting having personally felt discriminated against or harassed in the previous 12 months on the basis of a ground of discrimination prohibited under international human rights law

11.2.1* Proportion of population that has convenient access to public transport, by sex, age, and persons with disabilities

11.5.1 Number of deaths, missing persons, and directly affected persons attributed to disasters per 100,000 people

11.7.1* Average share of the builtup area of cities that is open space for public use for all, by sex, age, and persons with disabilities

11.7.2* Proportion of persons victim of physical or sexual harassment, by sex, age, disability status, and place of occurrence, in the previous 12 months

13.1.1 Number of deaths, missing persons, and directly affected persons attributed to disasters per 100,000 people

13.b.1* Number of least developed countries and small island developing states that are receiving specialized support; and amount of support, including finance, technology and capacity-building, for mechanisms for raising capacities for effective climate change-related planning and management, including focusing on women, youth, and local and marginalized communities

16.1.1* Number of victims of intentional homicide per 100,000 population, by sex and age

16.1.2* Conflict-related deaths per 100,000 population, by sex, age, and cause

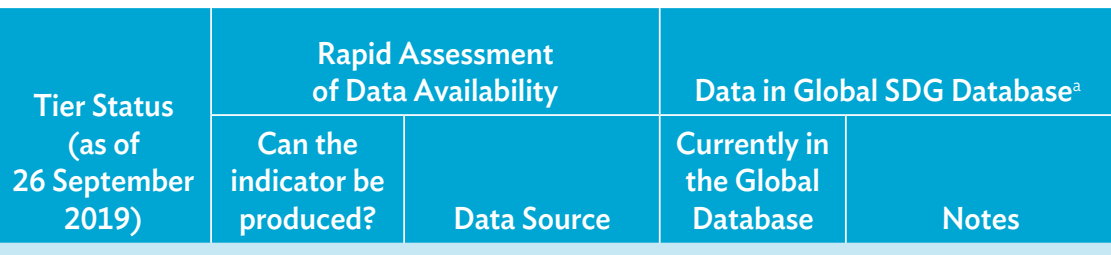

Tier 2

No

No
Tier 3

No

$\begin{array}{lll}\text { Tier } 2 \text { Yes } & \begin{array}{l}\text { National Disaster No } \\ \text { Management } \\ \text { Office }\end{array}\end{array}$

Tier 3

No $\begin{array}{lll}\text { Tier } 1 & \text { Yes } & \text { Police records }\end{array}$

Tier 2

No 
Appendix table continued

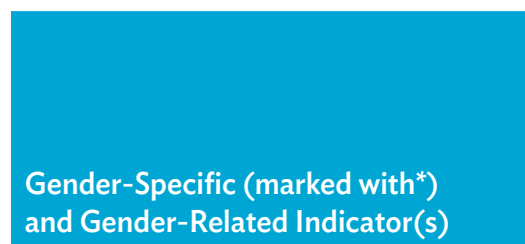

16.1.3* Proportion of population subjected to physical, psychological, or sexual violence in the previous 12 months

16.2.2* Number of victims of human trafficking per 100,000 population, by sex, age, and form of exploitation

16.2.3* Proportion of young women and men age 18-29 years who experienced sexual violence by age 18

16.3.1 Proportion of victims of violence in the previous 12 months who reported their victimization to competent authorities or other officially recognized conflict resolution mechanisms

16.5.1 Proportion of persons who had at least one contact with a public official and who paid a bribe to a public official, or were asked for a bribe by those public officials, during the previous 12 months

16.7.1* Proportions of positions (by sex, age, persons with disabilities, and population groups) in public institutions (national and local legislatures, public service, and judiciary) compared to national distributions

16.7.2* Proportion of population who believe decision-making is inclusive and responsive, by sex, age, disability, and population group

16.9.1 Proportion of children under 5 years of age whose births have been registered with a civil authority, by age

16.b.1* Proportion of population reporting having personally felt discriminated against or harassed in the previous 12 months on the basis of a ground of discrimination prohibited under international human rights law

\begin{tabular}{c|c|c|c|c|}
\multirow{2}{*}{$\begin{array}{c}\text { Tier Status } \\
\text { (as of }\end{array}$} & \multicolumn{2}{|c|}{$\begin{array}{c}\text { Rapid Assessment } \\
\text { of Data Availability }\end{array}$} & \multicolumn{2}{c}{ Data in Global SDG Database ${ }^{\text {a }}$} \\
\cline { 2 - 4 } $\begin{array}{c}\text { 26 September } \\
2019)\end{array}$ & $\begin{array}{c}\text { Can the } \\
\text { indicator be } \\
\text { produced? }\end{array}$ & Data Source & $\begin{array}{c}\text { Currently in } \\
\text { the Global } \\
\text { Database }\end{array}$ & Notes \\
\hline
\end{tabular}

Tier 2

No

No

$\begin{array}{lll}\text { Tier } 2 \text { No No } & \text { No }\end{array}$

$\begin{array}{lll}\text { Tier } 2 \text { No No } & \text { No }\end{array}$

$\begin{array}{lll}\text { Tier } 2 \text { No No } & \text { No }\end{array}$

$\begin{array}{lll}\text { Tier } 2 \text { No No } & \text { No }\end{array}$

$\begin{array}{lll}\text { Tier } 2 \text { No } & \text { No }\end{array}$

$\begin{array}{lll}\text { Tier } 2 \text { No No } & \text { No }\end{array}$

Tier 12017 Integrated Yes

Child Nutrition

and Health

Survey

$\begin{array}{lll}\text { Tier } 2 \text { No No } & \text { No }\end{array}$ 
Appendix table continued

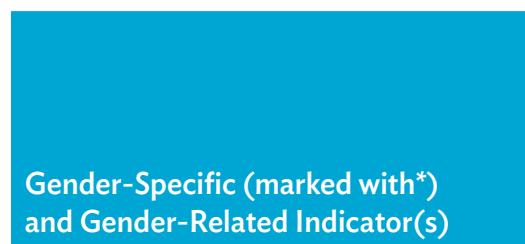

17.8.1 Proportion of individuals using the internet

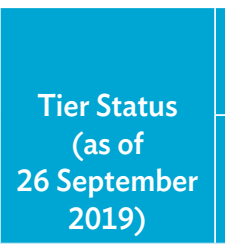

Tier 1

\section{Can the \\ indicator be \\ produced?}

Rapid Assessment

of Data Availability

Data Source

2011 census

captured

household

internet usage

only
17.18.1* Proportion of sustainable development indicators produced at the national level with full disaggregation when relevant to the target, in accordance with the Fundamental Principles of Official Statistics
Tier 3
Data in Global SDG Database

Currently in

the Global

Database

Notes

SDG = Sustainable Development Goals.

a The Global SDG Database is maintained by the United Nations Statistics Division. https://unstats.un.org/sdgs/indicators/database/. It collates data from a range of national and international sources, classifying each data point as country data, country adjusted, estimated, global monitoring data, modelled, nonrelevant, or not available. Data availability indicated is as of 11 August 2019.

* Gender-specific data.

Sources: Based on the authors' assessment of various reports of the Government of the Marshall Islands: The 2011 Population and Housing Census, the 2007 Demographic and Health Survey, the 2012 Family Health and Safety Study, the 2012 Labour Force Survey, the 2018 Household Income and Expenditure Survey, and administrative data. 


\section{Marshall Islands Gender Equality Overview}

\section{Key Statistics for Informed Decision-Making in Celebration of Beijing+25}

This publication uses graphics to summarize gender statistics from the Marshall Islands to help inform policy and planning. It draws on the latest key data collections, including the 2011 Population and Housing Census, the 2007 Demographic and Health Survey, the 2012 Family Health and Safety Study, the 2012 Labour Force Survey, and other data on education, health, and law enforcement. This resource supports the use of gender data for evidence-based policy making and rigorous monitoring and evaluation of progress toward transformative change. It also aims to encourage countries in the Pacific to continue to invest in data collection and research to strengthen capacity for gender analysis.

\section{About the Asian Development Bank}

ADB is committed to achieving a prosperous, inclusive, resilient, and sustainable Asia and the Pacific, while sustaining its efforts to eradicate extreme poverty. Established in 1966, it is owned by 68 members -49 from the region. Its main instruments for helping its developing member countries are policy dialogue, loans, equity investments, guarantees, grants, and technical assistance. 